\title{
The choroid plexus transcriptome reveals changes in type I and II interferon responses in a mouse model of Alzheimer's disease
}

\author{
Sandro Dá Mesquita a,b ${ }^{\mathrm{a}}$, Ana C. Ferreira ${ }^{\mathrm{a}, \mathrm{b}}$, Fuying Gao ${ }^{\mathrm{c}}$, Giovanni Coppola ${ }^{\mathrm{c}}$, Daniel H. Geschwind ${ }^{\mathrm{c}}$, \\ João C. Sousa ${ }^{\mathrm{a}, \mathrm{b}}$, Margarida Correia-Neves ${ }^{\mathrm{a}, \mathrm{b}}$, Nuno Sousa ${ }^{\mathrm{a}, \mathrm{b}}$, Joana A. Palha ${ }^{\mathrm{a}, \mathrm{b}}$, Fernanda Marques ${ }^{\mathrm{a}, \mathrm{b}, *}$ \\ ${ }^{a}$ Life and Health Sciences Research Institute (ICVS), School of Health Sciences, University of Minho, Campus Gualtar, $4710-057$ Braga, Portugal \\ bICVS/3B's - PT Government Associate Laboratory, Braga/Guimaraes, Portugal \\ ${ }^{\mathrm{c}}$ Program in Neurogenetics, Department of Neurology, David Geffen School of Medicine - University of California, Los Angeles, CA, USA
}

\section{A R T I C L E I N F O}

\section{Article history:}

Received 19 March 2015

Received in revised form 29 May 2015

Accepted 10 June 2015

Available online 16 June 2015

\section{Keywords:}

Alzheimer's disease

Aging

Memory

Choroid plexus

Transcriptome

Neuroinflammation

Interferons

Cerebrospinal fluid

Hippocampus

Glial cells

\begin{abstract}
A B S T R A C T
Alzheimer's disease (AD) is a neurodegenerative disorder characterized by a marked decline in cognition and memory function. Increasing evidence highlights the essential role of neuroinflammatory and immune-related molecules, including those produced at the brain barriers, on brain immune surveillance, cellular dysfunction and amyloid beta $(\mathrm{A} \beta)$ pathology in $\mathrm{AD}$. Therefore, understanding the response at the brain barriers may unravel novel pathways of relevance for the pathophysiology of AD. Herein, we focused on the study of the choroid plexus (CP), which constitutes the blood-cerebrospinal fluid barrier, in aging and in AD. Specifically, we used the PDGFB-APPSwInd (J20) transgenic mouse model of AD, which presents early memory decline and progressive $A \beta$ accumulation, and littermate age-matched wild-type (WT) mice, to characterize the CP transcriptome at 3, 5-6 and 11-12 months of age. The most striking observation was that the $\mathrm{CP}$ of $\mathrm{J} 20$ mice displayed an overall overexpression of type I interferon (IFN) response genes at all ages. Moreover, J20 mice presented a high expression of type II IFN genes in the $\mathrm{CP}$ at 3 months, which became lower than WT at 5-6 and 11-12 months. Importantly, along with a marked memory impairment and increased glial activation, J20 mice also presented a similar overexpression of type I IFN genes in the dorsal hippocampus at 3 months. Altogether, these findings provide new insights on a possible interplay between type I and II IFN responses in AD and point to IFNs as targets for modulation in cognitive decline.
\end{abstract}

(c) 2015 Elsevier Inc. All rights reserved.

\section{Introduction}

Alzheimer's disease (AD) is the most prevalent form of dementia and is predicted to affect eighty million people worldwide by 2040 (Ballard et al., 2011; Querfurth and LaFerla, 2010). The major constraint of $\mathrm{AD}$ patients is the severe loss of cognitive abilities (Ballard et al., 2011). Moreover, this neurodegenerative disease is characterized by two main brain pathological hallmarks: the extracellular deposition of amyloid beta $(A \beta)$ peptides, in the form of senile plaques, and the formation of intracellular neurofibrillary tangles, as a result of increased aggregation of hyperphosphorylated Tau protein (Gotz et al., 2001; Hardy and Selkoe, 2002; Lewis et al., 2001; Scheuner et al., 1996). The amyloidogenic hypothesis of $\mathrm{AD}$ considers that amyloid pathology may result

* Corresponding author at: Life and Health Sciences Research Institute (ICVS), School of Health Sciences, University of Minho, Campus Gualtar, 4710-057 Braga, Portugal.

E-mail address: fmarques@ecsaude.uminho.pt (F. Marques). from increased $A \beta$ production, through the amyloidogenic processing of the amyloid precursor protein (APP), and/or decreased excretion of $A \beta$ out of the brain (Hardy and Selkoe, 2002; Roberson and Mucke, 2006). In fact, oligomerization of $A \beta$ peptides in the brain has been described as an early pathogenic event that is responsible for behavior alterations (Mucke et al., 2000; Palop and Mucke, 2010). However, regardless of the attention given to increased $A \beta$ formation and toxicity in the brain, neuroinflammation is also recognized as an early and essential mediator of brain pathology and behavior alteration in AD (Lucin and Wyss-Coray, 2009; Wyss-Coray, 2006). In this context, two relevant emerging concepts should be considered: (I) the age-associated changes in the blood composition and (II) the levels/ratio of type I and II interferon (IFN) cytokines. Regarding the first concept, recent observations showed the involvement of the systemic milieu in memory formation and the role of specific inflammatory molecules in age-related decreased synaptic plasticity and memory function (Baruch et al., 2013; Villeda et al., 2011). Regarding the second concept, an enhanced type I IFN signaling at the brain barriers, and 
decreased type II IFN response, have recently been implicated in cognitive decline in aged mice (Baruch et al., 2014).

Of relevance, the brain barriers, namely the blood-brain barrier, composed by the endothelial cells of the blood capillaries, and the blood-cerebrospinal (CSF) barrier, formed by the choroid plexus (CP) epithelial cells, seems to influence both the excretion of $A \beta$ peptides out of the brain (Carro et al., 2002, 2005; Zlokovic, 2008) and the inflammatory response (Marques et al., 2009, 2013; Zlokovic, 2008). Particularly, besides its role in the formation and secretion of the CSF, recent studies clearly indicate that the CP is able to modulate the cognitive function, through changes in the neuroinflammatory response and in brain immune surveillance (Baruch et al., 2013, 2014; Baruch and Schwartz, 2013). Interestingly, the role of the $\mathrm{CP}$ in the neuroinflammatory response in $\mathrm{AD}$, as well as its connection with impaired memory and cognition, is still poorly understood and is addressed in the present study. Specifically, we took advantage of a mouse model of AD that presents early cognitive deficits and brain amyloid pathology, the PDGFB-APPSwInd (J20) (Mucke et al., 2000), and respective wild-type (WT) age-matched littermates, to study changes in the $\mathrm{CP}$ transcriptome and in the composition of the CSF. Furthermore, we analyzed the extension of the changes observed at the level of the $\mathrm{CP}$, by assessing the neuroinflammatory response at the dorsal hippocampus (dHPC), a brain region that is seriously affected in AD (Palop et al., 2007; Villeda et al., 2011). Altogether, the results suggest that alterations in IFN signaling may contribute to neuroinflammation, amyloid pathology and cognitive impairment in aging and in AD.

\section{Materials and methods}

\subsection{Ethics statement}

Animal handling and experimental procedures were conducted in accordance with the Portuguese national authority for animal experimentation, Direção Geral de Veterinária (ID: DGV9457). Animals were kept in accordance with the guidelines for the care and handling of laboratory animals in the Directive 2010/63/EU of the European Parliament and the Council. The animals were housed and maintained in a controlled environment at $22-24{ }^{\circ} \mathrm{C}$ and 55\% humidity, on $12 \mathrm{~h}$ light/dark cycles and fed with regular rodent's chow and tap water ad libitum.

\subsection{Animal model and experimental groups}

Male hemizygous B6.Cg-Tg(PDGFB-APPSwInd)20Lms/2J/Mmjax (J20) mice, in a C57BL/6J background, first developed by Professor Lennart Mucke, of The J. David Gladstone Institutes (San Francisco, CA, USA), were purchased from The Jackson Laboratory (Bar Harbor, Maine, USA). The J20 mice express a mutant form of the human APP bearing both the Swedish (K670N/M671L) and the Indiana (V717F) mutations (APPSwInd). Expression of the transgenic insert is directed by the human platelet-derived growth factor beta polypeptide (PDGFB) promoter (Mucke et al., 2000). Hemizygous mice present the highest expression of the transgene product in neurons of the neocortex and HPC. At 5-7 months of age diffuse $A \beta$ peptides deposition is detected in the dentate gyrus (DG) and neocortex. Amyloid deposition is progressive with all transgenic mice exhibiting plaques by the age of $8-10$ months (Mucke et al., 2000; Palop et al., 2007). Both hemizygous transgenic J20 mice and age-matched non-carrier WT littermates (all males) were used. Male mice were divided, according to age, into three groups: 3 months, 5-6 months and 11-12 months. These ages were chosen in order to assess the changes in behavior, at the blood-CSF barrier and in the brain parenchyma, at different stages of $A \beta$ pathology, particularly before and after $A \beta$ plaque formation. The value of achieved power $(1-\beta)$ of the sample was calculated using the IBM SPSS Statistics for Windows (Version 23.0. Armonk, NY: IBM Corp, USA), on the basis of the sample size $(N=80)$ and effect size (partial eta squared $=0.044)$ associated with the Morris water maze (MWM) test, which was analyzed by a parametric repeated measures two-way ANOVA $(\alpha=0.05)$. Taking that the Mauchly's Test revealed a violation of sphericity for the analyzed groups, the Huynh-Feldt correction was applied and a final value of $1-\beta=0.841$ was obtained, which is considered to be statistically powerful (Mazen et al., 1985).

\subsection{MWM paradigm}

Memory was evaluated during the light phase of the diurnal cycle using the MWM paradigm. The MWM was performed in a white circular pool $(170 \mathrm{~cm}$ in diameter and $50 \mathrm{~cm}$ in height), filled with tap water $\left(23 \pm 1{ }^{\circ} \mathrm{C} ; 30 \mathrm{~cm}\right.$ of depth) and placed in a poorly lit room. The water tank was divided into four imaginary quadrants (north, east, south, and west), each corresponding to a fixed extrinsic clue visible to the mouse. A transparent escape platform $(14 \mathrm{~cm}$ in diameter and $30 \mathrm{~cm}$ high), invisible to the mouse, was placed in the center of one of the quadrants and was maintained in that same position during the five days of the acquisition. For spatial reference-memory acquisition, a HPC-dependent task, the mice were placed randomly in one of the quadrants in each trial, and allowed to search for the hidden platform. During the five days of the acquisition phase, each mouse performed four trials per day. Each trial was concluded when the platform was reached within the time-limit of $120 \mathrm{~s}$. If failing to reach the platform within this time-period, the mouse was guided to the platform and allowed to stay in it for $30 \mathrm{~s}$. The four random consecutive trials of each day were video-captured with a video-tracking system (Viewpoint, Champagne au Mont d'or, France) and the mean values of the time (latency to platform) and speed to reach the platform were calculated. To analyze the MWM performance, mice were divided into groups according to their age and genotype. After two independent experiments with identical results, the final number of mice per group was the following: at 3 months, $N$ $(\mathrm{WT})=16$ and $N(\mathrm{~J} 20)=8$; at $5-6$ months, $N(\mathrm{WT})=8$ and $N$ $(\mathrm{J} 20)=10$; at $11-12$ months, $N(\mathrm{WT})=23$ and $N(\mathrm{~J} 20)=15$.

\subsection{Tissue sample collection and storage}

During the light phase of the diurnal cycle, specifically in the morning, mice were anesthetized with an intraperitoneal injection of a mixture of ketamine hydrochloride $\left(150 \mathrm{mg} / \mathrm{kg}\right.$, Imalgene ${ }^{\circledR}$ $1000)$ and medetomidine hydrochloride $\left(0.3 \mathrm{mg} / \mathrm{kg}\right.$, Dorben $\left.{ }^{\circledR}\right)$. Under deep anesthesia, CSF samples were collected from the cisterna magna and checked for blood contamination using a haemocytometer. Samples were stored at $-80^{\circ} \mathrm{C}$ until further use. After this, mice were transcardially perfused with $0.9 \%$ saline and the brains were removed from the skull. For gene expression analysis by microarray and qRT-PCR, the CP samples from each brain ventricle of the same mouse were rapidly removed under a conventional light stereomicroscope (SZX7, Olympus, Hamburg, Germany), pooled, snap-frozen and stored at $-80^{\circ} \mathrm{C}$. Specific brain areas, namely the dHPC, were obtained by macrodissection, snap-frozen and stored at $-80^{\circ} \mathrm{C}$, for RNA extraction and gene expression analysis. Whole brains were fixed in $4 \%$ paraformaldehyde (PFA, Panreac Química S.L.U., Barcelona, Spain) for $48 \mathrm{~h}$ and kept in paraffin blocks until further sectioning. Alternatively, brains were immediately embedded in Richard-Allan Scientific ${ }^{\mathrm{TM}}$ Neg-50 ${ }^{\mathrm{TM}}$ Frozen Section Medium (ThermoFisher Scientific, Waltham, MA, USA), snap-frozen and kept frozen at $-20^{\circ} \mathrm{C}$ until further sectioning. 


\subsection{Microarray and Ingenuity ${ }^{\circledR}$ Pathway Analysis}

Total RNA was extracted from CP tissue using the RNeasy ${ }^{\circledR}$ Plus Micro Kit (Qiagen, Hamburg, Germany), following the manufacturer's instructions. After quality assessment using the Agilent Bioanalyzer (Agilent Technologies, CA, USA), $500 \mathrm{ng}$ of total RNA were used for T7-based mRNA amplification using the manufactured kit TargetAmp ${ }^{\mathrm{TM}} 2$ - Round Biotin aRNA Amplification Kit 3.0 (Epicentre, Illumina, Wisconsin, USA), according to the manufacturer's instructions. The quality of amplified RNA was assessed using an Agilent Bioanalyzer. Amplified RNA was labeled and hybridized to Illumina Mouse Ref 8 v2.0 gene expression BeadChips, querying the expression of approximately 25,600 RefSeq-curated gene targets, for microarray analysis by the Southern California Genotyping Consortium (SCGC) core using the Illumina BeadStation platform. Statistical microarray analysis and gene expression analysis were performed at the Informatics Center for Neurogenetics and Neurogenomics (ICNN) core at UCLA using R (www.r-project.org) and Bioconductor (www.bioconductor.org) packages as described before (Coppola, 2011; Coppola et al., 2008). The raw data was deposited in the GEO database, accession number GEO: GSE66598. Gene pathway and functional analysis was performed using the Ingenuity Pathway Analysis 6.0 (IPA; Ingenuity ${ }^{\circledR}$ Systems, www.ingenuity.com). The $\mathrm{CP}$ transcriptome of WT mice at $3(N=3), 5-6(N=4)$ and 11-12 $(N=6)$ months, and of J20 mice at $3(N=4), 5-6(N=4)$ and 11$12(N=3)$ months, was analyzed and compared. The individual data sets consisted on: (I) the comparison between the CP transcriptome of $\mathrm{J} 20$ mice and the $\mathrm{CP}$ transcriptome of WT mice, at different ages; (II) the comparison between the $\mathrm{CP}$ transcriptome of 11-12 months-old mice and that of 3 months-old mice, for each genotype independently. The data sets containing the accession numbers, the $\log$ ratio and the $p$-value for each gene, whose expression was significantly changed ( $p$-value $<0.05$ ), were uploaded into the IPA database. Using IPA and its applications, each gene identifier was mapped and the genes were used to build networks associated with a specific canonical pathway or with a relevant biological function or disease, according to the IPA database library. The Ingenuity ${ }^{\circledR}$ Upstream Regulator Analysis computed an activation $z$-score and a Fisher's exact $p$-value (overlap $p$-value) for the most altered genes. Furthermore, we used the IPA Upstream Regulator application to assemble an interactome using the five upstream regulators with the highest activation $z$-scores and the five upstream regulators with the lowest activation $z$-scores, along with the corresponding downstream target genes/molecules whose expression was significantly altered in the $\mathrm{CP}$ of $\mathrm{J} 20$ mice at each age. To be included in the interactome, the networks had to present at least one connection with an upstream regulator or with a downstream gene of a different adjacent network; orphan networks were not presented.

\subsection{Primary cultures of $C P$ epithelial cells and incubation with $A \beta_{1-42}$}

Primary cultures of CP epithelial cells were prepared from the $\mathrm{CP}$ tissue of rat pups due to the higher cellular yield of the isolation procedure when compared to the mouse $\mathrm{CP}$. This procedure was performed as described before (Marques et al., 2009), with minor modifications. Briefly, neonates (P5-P7) were sacrificed and the $\mathrm{CP}$ dissected from the four brain ventricles, under a conventional light stereomicroscope (SZX7, Olympus). The tissue was rinsed in phosphate buffer saline (PBS, Invitrogen, Carlsbad, CA, USA) without $\mathrm{Ca}^{2+}$ and $\mathrm{Mg}^{2+}$, followed by a 25 min digestion with $0.1 \mathrm{mg} / \mathrm{mL}$ pronase (Sigma-Aldrich, St. Louis, MO, USA) at $37^{\circ} \mathrm{C}$. Predigested tissue was recovered by sedimentation and briefly shaken in $0.025 \%$ trypsin-EDTA (Invitrogen) containing $12.5 \mu \mathrm{g} / \mathrm{ml}$ DNAse I (Roche, Amadora, Portugal). The supernatant was then withdrawn and kept on ice with $10 \%$ fetal bovine serum (FBS, Invitrogen). This step was repeated five times. Cells were collected by centrifugation and re-suspended in culture media consisting of Ham's F-12 and Dulbecco's modified Eagle's medium (DMEM-F12, Invitrogen) supplemented with $10 \%$ FBS, $2 \mathrm{mM}$ glutamine, $50 \mathrm{mg} / \mathrm{mL}$ gentamycin, $5 \mathrm{mg} / \mathrm{mL}$ insulin, $5 \mathrm{mg} / \mathrm{mL}$ transferrin, $5 \mathrm{ng} / \mathrm{mL}$ sodium selenite, $10 \mathrm{ng} / \mathrm{mL}$ epidermal growth factor, $2 \mathrm{mg} / \mathrm{mL}$ hydrocortisone and $5 \mathrm{ng} / \mathrm{mL}$ basic fibroblast growth factor (all from Sigma-Aldrich). For further enrichment, cells were incubated on plastic dishes for $2 \mathrm{~h}$ at $37^{\circ} \mathrm{C}$. The supernatant containing the $\mathrm{CP}$ epithelial cells was collected and placed for seeding on $0.4 \mu \mathrm{m}$ pore size transwells (Corning Life Sciences, Lowell, MA, USA) coated with laminin (BD Biosciences, Bedford, MA, USA) at a density of $1 \times 10^{5}$ cells $/ \mathrm{cm}^{2}$. The culture medium was changed every two days and $\mathrm{CP}$ epithelial cells were maintained in culture for 5-7 days, at $37{ }^{\circ} \mathrm{C}$ in a humid atmosphere $\left(5 \% \mathrm{CO}_{2}\right)$, before performing the experiment. To assess the cellular purity and confluence after 7 days in culture, an immunofluorescent staining was performed, using a primary antibody for transthyretin (TTR) (kindly provided by Dr. Maria Joao Saraiva, Institute for Molecular and Cell Biology, Porto, Portugal), a specific marker of CP epithelial cells (Sousa et al., 2007). Cell counting revealed that $\geqslant 95 \%$ of the cells stained positive for TTR. Stock $A \beta_{1-42}$ (American Peptide Company, Sunnyvale, CA, USA) was prepared by dissolving the peptides in Tris- $\mathrm{NaCl}$ buffer $(150 \mathrm{mM} \mathrm{NaCl}$ and $50 \mathrm{mM}$ Tris- $\mathrm{HCl} \mathrm{pH} 7.4$, all from Sigma-Aldrich) to a final concentration of $221.5 \mu \mathrm{M}$ and kept at $-80^{\circ} \mathrm{C}$. After reaching confluence, $\mathrm{CP}$ epithelial cells were incubated for $60 \mathrm{~h}$ with DMEM-F12 alone (vehicle) or a solution of $1 \mu \mathrm{M}$ monomeric/dimeric $A \beta_{1-42}$, by dissolving stock $A \beta_{1-42}$ in DMEM-F12 medium.

\subsection{Primary cultures of astrocytes and neurons}

This procedure was performed as described before (Mesquita et al., 2014). Details are provided in Supplementary methods (Appendix A).

\subsection{Gene expression analysis by $q R T-P C R$}

The quality assessment and quantification of the total RNA extracted from CP samples was performed in the NanoDrop ${ }^{\circledR}$ ND-1000 and $350 \mathrm{ng}$ of RNA from each sample were amplified using the MessageAmp ${ }^{\mathrm{TM}}$ II aRNA Amplification Kit (Ambion, Carlsbad, CA, USA) according to the manufacturer's instructions. Total RNA was also extracted from primary cultures of CP epithelial cells, using the RNeasy ${ }^{\circledR}$ Plus Micro Kit (Qiagen), or from samples of dHPC, using the Trizol reagent (Invitrogen), following the manufacturer's instructions. Then, after quantification in the NanoDrop ${ }^{\circledR}$, $500 \mathrm{ng}$ of total or amplified RNA from each sample was reverse transcribed into cDNA using the iScript ${ }^{\mathrm{TM}} \mathrm{cDNA}$ Synthesis Kit (Bio-Rad Laboratories, Hercules, CA, USA) following the manufacturer's instructions. Primers used to measure the expression levels of selected mRNA transcripts by qRT-PCR were designed using the Primer-BLAST tool of the National Center for Biotechnology Information (Bethesda, MD, USA) on the basis of the respective GenBank accession numbers. The reference gene hypoxanthine guanine phosphoribosyl transferase (Hprt) was used as internal standard for the normalization of the expression of selected transcripts. All GenBank accession numbers for Mus musculus (in vivo studies) or Rattus norvegicus (in vitro experiments) gene transcripts and primer DNA sequences are provided in Supplementary data (Appendix A). Annealing temperatures are available on request. The qRT-PCR was performed on a CFX 96TM real-time system instrument (Bio-Rad), with the SsoFast ${ }^{\mathrm{TM}}$ EvaGreen $^{\circledR}$ Supermix (Bio-Rad) according to the manufacturer's instructions, using equal amounts of cDNA from each sample. The cycling parameters were 
1 cycle at $95{ }^{\circ} \mathrm{C}$ for $15 \mathrm{~min}$, followed by 40 cycles at $94{ }^{\circ} \mathrm{C}$ for $15 \mathrm{~s}$, annealing temperature (primer specific) for $30 \mathrm{~s}$ and $72^{\circ} \mathrm{C}$ for $30 \mathrm{~s}$, finishing with 1 cycle at $65^{\circ} \mathrm{C}$ to $95^{\circ} \mathrm{C}$ for $5 \mathrm{~s}$ (melting curve). Product fluorescence was detected at the end of each elongation cycle. All melting curves exhibited a single sharp peak at the expected temperature.

\subsection{Quantification of $A \beta$ and IFN- $\alpha$ in the CSF}

The quantification of $A \beta$ in the CSF was performed by a direct enzyme-linked immunosorbent assay (ELISA) performed in Nunc MaxiSorp ${ }^{\circledR}$ flat-bottom 96-well plates (ThermoFisher Scientific). The wells were coated with $1 \mu \mathrm{L}$ of CSF diluted in $99 \mu \mathrm{L}$ of a $\mathrm{KH}_{2} \mathrm{PO}_{4} / \mathrm{K}_{2} \mathrm{HPO}_{4}$ buffer ( $\mathrm{pH}$ 8.0) solution (1:100 dilution factor), for $2 \mathrm{~h}$ at $37^{\circ} \mathrm{C}$. After washing with PBS $0.05 \%$ Tween ${ }^{\circledR} 20$ (Sigma-Aldrich), a blocking step with PBS 10\% skim milk (Nestle S.A., Linda-a-Velha, Portugal) was performed for $1 \mathrm{~h}$ at room-temperature (RT). Then, consecutive incubations for $1 \mathrm{~h}$ at RT were performed: first with rabbit anti-human $A \beta$ (1:500, D54D2, Cell Signaling Technology, Danvers, MA, USA), second with biotinylated horse anti-rabbit (1:500, Vector Laboratories, Burlingame, CA, USA) and third with streptavidin-horseradish peroxidase (1:2500, Sigma-Aldrich). Each incubation step was separated by thorough washes with PBS $0.05 \%$ Tween $^{\circledR} 20$ and PBS. Finally, the detection of $A \beta$ was achieved by adding a solution containing 2,2'-azino-bis(3-ethylbenzothiazoline-6-sulfonic acid) diammonium salt (ABTS, Sigma-Aldrich), which induced a colorimetric reaction read at $405 \mathrm{~nm}$. The standard curve was obtained using known concentrations of human $A \beta_{1-42}$ (American Peptide Company, Sunnyvale, CA, USA) that ranged from 0.1 to $100 \mathrm{ng} / \mu \mathrm{L}$ (considering the linearity of the assay). The levels of IFN- $\alpha$ were measured in $1 \mu \mathrm{L}$ of CSF, using the commercially available Mouse IFN alpha Platinum ELISA kit (Affymetrix, eBioscience, Vienna, Austria), according to the manufacturer's instructions. The standard curve was obtained using known concentrations of mouse IFN- $\alpha$ that ranged from 31.3 to $2000 \mathrm{pg} / \mathrm{mL}$.

\subsection{Immunofluorescent staining for $A \beta$ peptides}

Serial sections of frozen brain (coronal sections) with a thickness of $20 \mu \mathrm{m}$ were cut in the cryostat and collected to SuperFrost ${ }^{\circledR}$ Plus slides (ThermoFisher Scientific). Sections were then fixed for $20 \mathrm{~min}$ in 4\% PFA (Panreac), at RT. A step of antigen retrieval was performed afterwards, by heating the tissue sections for $20 \mathrm{~min}$ in $10 \mathrm{mM}, \mathrm{pH} \mathrm{6.0,} \mathrm{acetic} \mathrm{acid} \mathrm{(Sigma-Aldrich).} \mathrm{After} \mathrm{a}$ blocking step for $1 \mathrm{~h}$ at RT, with a solution of $0.5 \%$ bovine serum albumin (BSA, Sigma-Aldrich) in PBS 0.3\% Triton X-100 (SigmaAldrich) (PBS-T), the tissue sections were incubated, overnight, with the primary antibody rabbit anti-human $A \beta$ (1:1000, D54D2, Cell Signaling) diluted in blocking solution. After this period, the sections were rinsed in PBS-T and incubated with a secondary antibody conjugated to Alexa-594 (1:500, Invitrogen) diluted in PBS-T for $1 \mathrm{~h}$ at RT. Finally, after incubation in a solution of 4,6-diamidino-2-phenylindole (DAPI, 1:1000, Invitrogen) in PBS for 5 min at RT, the sections were washed with PBS, and mounted in Shandon Immu-Mount (ThermoFisher Scientific). Fluorescence analysis and image capture were performed using a conventional fluorescence microscope (BX61; Olympus).

\subsection{Immunohistochemistry for glial fibrillary acidic protein (GFAP) and ionized calcium-binding adapter molecule 1 (IBA1)}

To assess the morphology of astrocytes and the number of microglia/macrophages from the DG of the dHPC, $10 \mu \mathrm{m}$ thick coronal brain sections were deparaffinized and antigen retrieval was performed by heating the tissue sections for $20 \mathrm{~min}$ in
$10 \mathrm{mM}$ acetic acid solution, pH 6.0 (Sigma-Aldrich). Next, tissue peroxidases were inactivated, by immersion in a $0.3 \% \mathrm{H}_{2} \mathrm{O}_{2}$ solution for $30 \mathrm{~min}$, and a blocking step was performed by incubation in a PBS-T $0.5 \%$ BSA solution. Sections were later incubated overnight, at RT, with rabbit anti-mouse GFAP (1:200, Dako, Golstrup, Denmark) or rabbit anti-mouse IBA1 (1:300, Wako Chemicals $\mathrm{GmbH}$, Neuss, Germany) antibodies diluted in blocking solution and, in the following day, rinsed in PBS-T and incubated with biotinylated goat polyvalent antibody (UltraVision Large Volume Detection System, ThermoFisher Scientific) for $1 \mathrm{~h}$ at RT. Finally, after rinsing in PBS-T, sections were further incubated for $1 \mathrm{~h}$ with streptavidin- horseradish peroxidase (UltraVision, ThermoFisher Scientific), rinsed again in PBS and exposed to a 3,3-diaminobenzidine solution (Sigma-Aldrich) for $10 \mathrm{~min}$. After a thorough wash with PBS, sections were dried and mounted in Entellan (Merck, Darmstadt, Germany). The morphology of 10 astrocytes $\left(\mathrm{GFAP}^{+}\right.$cells) located in the DG of the dHPC of each mouse ( $N=30$ astrocytes/group) was assessed using an optical microscope (BX51TF, Olympus) coupled to a camera (U-TV1X-2, Olympus) and with the NeuroLucida software (Olympus). The samples were given a code name so that the morphology could be assessed by an investigator who was blinded to the experiment. Data was analyzed with the NeuroExplorer software (Olympus). The number of microglia/macrophages in the DG of the dHPC was assessed in serial brain sections and the number of cells per $\mathrm{mm}^{2}$ was calculated $(N=4 /$ group at 3 and 5-6 months, and $N=5 /$ group at $11-12$ months).

\subsection{Statistical analysis}

Values are reported as mean \pm standard error of mean (SEM). The number of biological replicates $(N)$ of the representative independent experiments is specified in the legend of each figure. Statistical significant differences between groups were determined using the parametric repeated measures two-way ANOVA with Bonferroni post hoc test (two-tailed) or the non-parametric two-tailed Mann Whitney test and Kruskal-Wallis with Dunns' multiple comparison test (two-tailed). Values were considered to be statistically significant for $p<0.05\left({ }^{*}\right), p<0.01\left(^{* *}\right)$ and $\left.p<0.001{ }^{(* *}\right)$. Simple correlations were obtained by regression analysis, using the Pearson's correlation test, and results were considered to be statistically significant for $p<0.05$ (two-tailed). Regression models (two-tailed) were designed and run in Matlab R2009b (7.9.0.529, Mathworks, Natick, MA, USA). To avoid collinearity, the independent variables age and IFN- $\alpha$ were centered, considering for that the respective mean values. To verify the statistical significance of the interactions between the different predictors, four interaction terms were created (age*genotype, age IFN- $\alpha$, genotype*IFN- $\alpha$ and age*genotype*IFN- $\alpha$ ). No animals were excluded from the analysis.

\section{Results}

\subsection{Age-associated memory decline was anticipated in J20 mice}

The MWM was used to test the performance of WT and J20 mice in a spatial reference-memory task at 3, 5-6 and 11-12 months of age (Fig. $1 \mathrm{~A}$ and $\mathrm{B}$ ). At 3 months, WT mice took significantly less time to find the hidden platform, when compared to age-matched J20 mice (Fig. 1B). At the ages of 5-6 months and 11-12 months, the differences between WT and J20 mice became smaller; still, at 11-12 months, J20 mice presented a significantly worst performance than WT mice at day 5 of the MWM (Fig. 1B). No statistical significant differences were observed in terms of swimming speed in the MWM, when comparing mice of different 
A

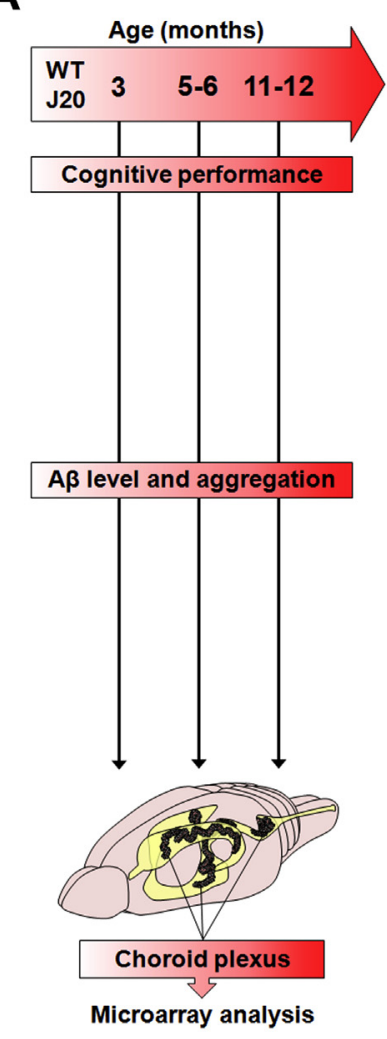

B

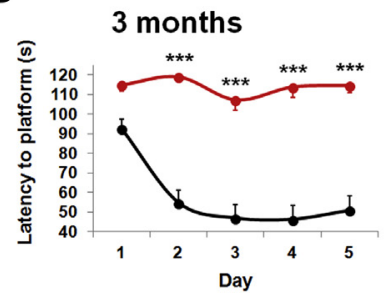

C

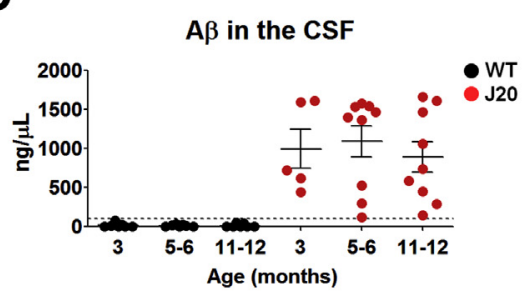

$\mathbf{E}$

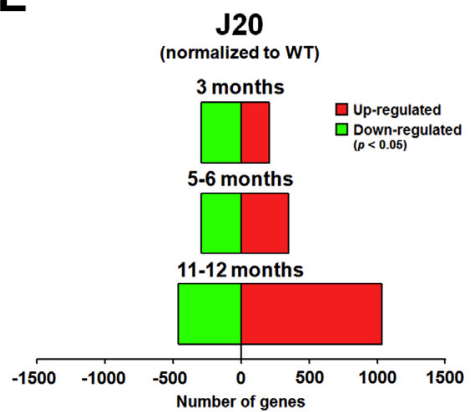

5-6 months

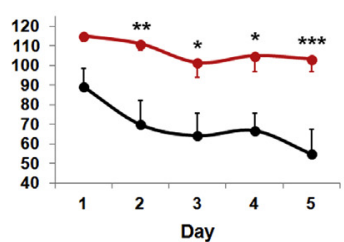

D

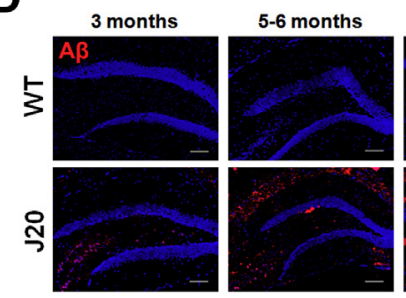

$\mathbf{F}$

J20

(normalized to WT)

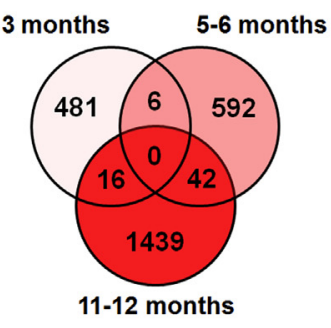

11-12 months

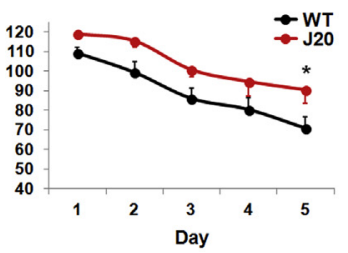

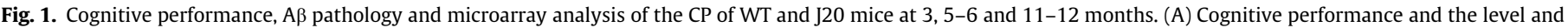

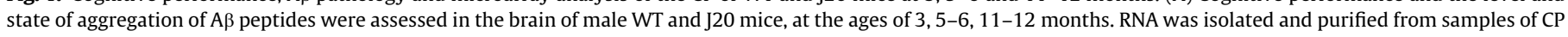

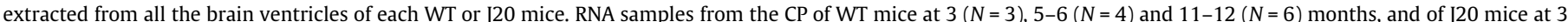

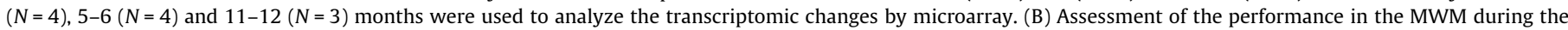

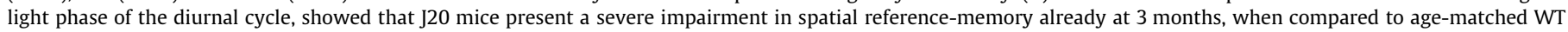

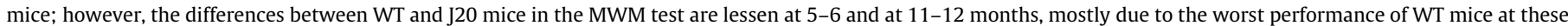

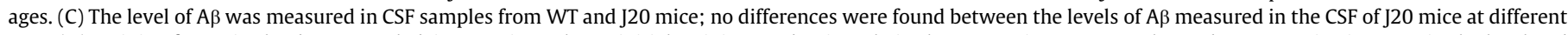

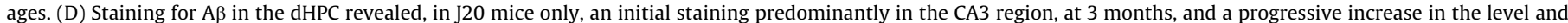

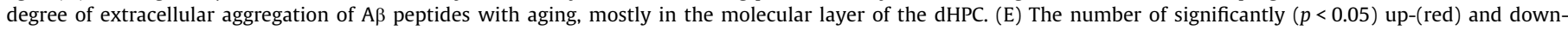

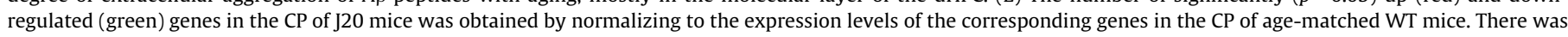

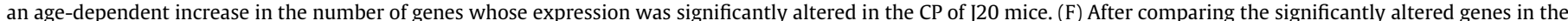

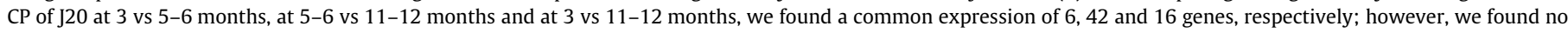

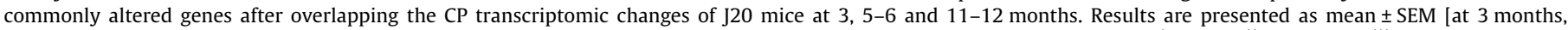

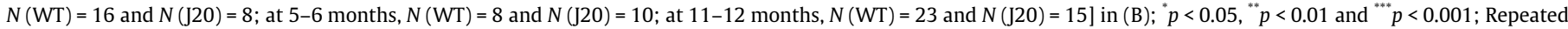

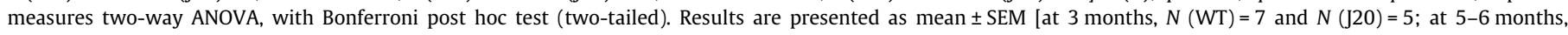

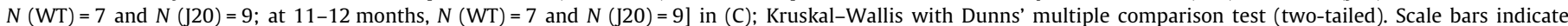
$100 \mu \mathrm{m}$ in (D).

genotypes at each age (Supplementary Fig. 1). To assess brain amyloid pathology in J20 mice, we measured the levels of A $\beta$ in the CSF and evaluated the degree of $A \beta$ aggregation and deposition in the dHPC (Fig. 1C and D). There were no statistically significant differences between the levels of A $\beta$ in the CSF of J20 mice at different ages (Fig. 1C); yet, there was a progressive accumulation of $A \beta$ and increased plaque burden in the dHPC of J20 mice with aging that was more obvious at 11-12 months (Fig. 1D). No A $\beta$ was detected in the CSF or in the brain of WT mice (Fig. 1C and D).

\subsection{Age and $A \beta$ impacted differently on the $C P$ transcriptome of $W T$ and of J20 mice}

The changes in the $\mathrm{CP}$ transcriptome of $\mathrm{J} 20$ mice were assessed by microarray at 3, 5-6 and 11-12 months of age and normalized to the changes observed in age-matched WT mice (Fig. 1A). The highest number of up- and down-regulated genes in the $\mathrm{CP}$ of J20 mice was observed at 11-12 months (Fig. 1E). Of notice, we found no commonly altered genes after overlapping the $\mathrm{CP}$ transcriptomic changes of J20 mice at 3, 5-6 and 11-12 months (Fig. 1F). Moreover, we found few commonly altered genes when comparing the transcriptomic changes in the $\mathrm{CP}$ of $\mathrm{J} 20$ mice two ages at a time (Fig. 1F). The ten most up- or down-regulated genes in the $\mathrm{CP}$ of $\mathrm{J} 20$ mice (Table 1 ) revealed alterations in genes that are involved in the functions classically attributed to the $\mathrm{CP}$, such as the modulation of the CSF's composition, and that regulate the survival of $\mathrm{CP}$ cells and the maintenance of the barrier integrity (Table 1). We also analyzed the effect of aging, per se, in the CP transcriptome, by normalizing the changes observed in WT or J20 mice at 11-12 months to that of 3 months-old mice of the same genotype (Supplementary Figs. 2 and 3). Interestingly, we found a consistent alteration in the expression of genes that regulate the cellular circadian rhythm in the 11-12 months-old mice, which is describe in detail in the Supplementary data (Supplementary Figs. 2 and 3 and Supplementary Tables 1 and 2). Surprisingly, when considering all the analyzed data sets and comparisons 
Table 1

Most altered genes in the $\mathrm{CP}$ of $\mathrm{J} 20$ mice (normalized to age-matched littermate WT mice).

\begin{tabular}{|c|c|c|c|c|c|c|c|c|c|}
\hline \multicolumn{5}{|l|}{ Up-regulated genes } & \multicolumn{5}{|c|}{ Down-regulated genes } \\
\hline $\begin{array}{l}\text { Accession } \\
\text { number }\end{array}$ & $\begin{array}{l}\text { Entrez Gene name } \\
\text { (Mus musculus) }\end{array}$ & $\begin{array}{l}\text { Gene } \\
\text { symbol }\end{array}$ & $\begin{array}{l}\text { Fold } \\
\text { change }\end{array}$ & $\begin{array}{l}p- \\
\text { value }\end{array}$ & $\begin{array}{l}\text { Accession } \\
\text { number }\end{array}$ & Entrez Gene name (Mus musculus) & $\begin{array}{l}\text { Gene } \\
\text { symbol }\end{array}$ & $\begin{array}{l}\text { Fold } \\
\text { change }\end{array}$ & $\begin{array}{l}p- \\
\text { value }\end{array}$ \\
\hline \multicolumn{10}{|c|}{3 months (J20 vs WT) } \\
\hline NM_011638.3 & Transferrin receptor & Tfrc & 1.64 & 0.007 & NM_011066.1 & Period circadian clock 2 & Per2 & -1.52 & 0.019 \\
\hline NM_011909.1 & $\begin{array}{l}\text { Ubiquitin specific } \\
\text { peptidase } 18\end{array}$ & Usp18 & 1.43 & 0.017 & NM_001033302.1 & $\begin{array}{l}\text { Circadian associated repressor of } \\
\text { transcription }\end{array}$ & Ciart & -1.38 & 0.024 \\
\hline NM_019498.1 & Olfactomedin 1 & Olfm1 & 1.33 & 0.011 & NM_008504.2 & Granzyme M (lymphocyte met-ase 1) & Gzmm & -1.36 & 0.027 \\
\hline NM_008728.2 & $\begin{array}{l}\text { Natriuretic peptide } \\
\text { receptor } 3\end{array}$ & Npr3 & 1.32 & 0.001 & NM_015750.1 & Sialidase 2 (cytosolic sialidase) & Neu2 & -1.33 & 0.038 \\
\hline NM_011819.1 & $\begin{array}{l}\text { Growth differentiation } \\
\text { factor } 15\end{array}$ & Gdf15 & 1.32 & 0.026 & NM_053147.2 & $\begin{array}{l}\text { Prostaglandin I2 (prostacyclin) } \\
\text { synthase }\end{array}$ & Ptgis & -1.31 & 0.021 \\
\hline NM_001039086.1 & $\begin{array}{l}\text { Rap guanine } \\
\text { nucleotide exchange } \\
\text { factor (GEF) } 1\end{array}$ & Rapgef1 & 1.28 & 0.007 & NM_008968.2 & TSC22 domain family, member 3 & $\operatorname{Tsc} 22 d 3$ & -1.30 & 0.012 \\
\hline NM_013769.1 & $\begin{array}{l}\text { Tight junction protein } \\
3\end{array}$ & Tjp3 & 1.24 & 0.038 & NM_001077364.1 & $\begin{array}{l}\text { DEAD (Asp-Glu-Ala-Asp) box helicase } \\
17\end{array}$ & $D d x 17$ & -1.30 & 0.044 \\
\hline NM_009423.2 & $\begin{array}{l}\text { Tnf receptor- } \\
\text { associated factor } 4\end{array}$ & Traf4 & 1.22 & 0.014 & NM_148941.1 & ELOVL fatty acid elongase 4 & Elovl4 & -1.29 & 0.009 \\
\hline NM_020278.2 & $\begin{array}{l}\text { Leucine-rich, glioma } \\
\text { inactivated } 1\end{array}$ & Lgi1 & 1.21 & 0.025 & NM_011072.2 & Profilin 1 & Pfn1 & -1.24 & 0.039 \\
\hline NM_138314.1 & $\begin{array}{l}\text { NME/NM23 family } \\
\text { member } 7\end{array}$ & Nme7 & 1.21 & 0.049 & XM_354652 & $\begin{array}{l}\text { 3-hydroxyanthranilate 3,4- } \\
\text { dioxygenase }\end{array}$ & Haao & -1.25 & 0.021 \\
\hline \multicolumn{10}{|c|}{ 5-6 months (J20 vs WT) } \\
\hline NM_033373.1 & $\begin{array}{l}\text { Keratin } 23 \text { (histone } \\
\text { deacetylase inducible) }\end{array}$ & Krt23 & 1.48 & 0.008 & NM_198110.1 & $\begin{array}{l}\text { Guanine nucleotide binding protein- } \\
\text { like } 3 \text { (nucleolar)-like }\end{array}$ & Gnl3l & -1.46 & 0.028 \\
\hline NM_021389.3 & $\begin{array}{l}\text { SH3-domain kinase } \\
\text { binding protein } 1\end{array}$ & Sh3kbp1 & 1.37 & 0.011 & NM_007751.1 & Cytochrome c oxidase subunit VIIIb & Cox8b & -1.44 & 0.007 \\
\hline NM_010789.1 & Meis homeobox 1 & Meis1 & 1.32 & 0.008 & NM_011213.1 & $\begin{array}{l}\text { Protein tyrosine phosphatase, receptor } \\
\text { type, F }\end{array}$ & Ptprf & -1.30 & 0.012 \\
\hline NM_138955.2 & $\begin{array}{l}\text { ATP-binding cassette, } \\
\text { sub-family G (WHITE), } \\
\text { member } 4\end{array}$ & Abcg4 & 1.29 & 0.010 & NM_010024.1 & Dopachrome tautomerase & Dct & -1.30 & 0.006 \\
\hline NM_021399 & $\begin{array}{l}\text { B-cell CLL/lymphoma } \\
\text { 11B (zinc finger } \\
\text { protein) }\end{array}$ & Bcl11b & 1.29 & 0.041 & NM_053110.2 & Glycoprotein (transmembrane) nmb & Gpnmb & -1.26 & 0.042 \\
\hline NM_024440.1 & Derlin 3 & Derl3 & 1.26 & 0.005 & NM_028756.2 & Solute carrier family 35, member A5 & Slc35a5 & -1.26 & 0.005 \\
\hline NM_021391.2 & $\begin{array}{l}\text { Protein phosphatase } 1 \text {, } \\
\text { regulatory (inhibitor) } \\
\text { subunit } 1 \mathrm{~A}\end{array}$ & Ppp1r1a & 1.26 & 0.040 & NM_026002 & Metadherin & $M t d h$ & -1.25 & 0.022 \\
\hline NM_011807 & $\begin{array}{l}\text { Discs, large homolog } 2 \\
\text { (Drosophila) }\end{array}$ & Dlg2 & 1.25 & 0.037 & NM_133995.1 & Ureidopropionase, beta & Upb1 & -1.21 & 0.006 \\
\hline NM_007669.2 & $\begin{array}{l}\text { Cyclin-dependent } \\
\text { kinase inhibitor } 1 \mathrm{~A} \\
\text { (p21, Cip1) }\end{array}$ & Cdkn1a & 1.24 & 0.047 & NM_023805.2 & Solute carrier family 38, member 3 & Slc38a3 & -1.20 & 0.031 \\
\hline NM_010630.1 & $\begin{array}{l}\text { Kinesin family } \\
\text { member } C 2\end{array}$ & Kifc2 & 1.23 & 0.033 & NM_145979.1 & $\begin{array}{l}\text { Chromodomain helicase DNA binding } \\
\text { protein } 4\end{array}$ & Chd4 & -1.20 & 0.045 \\
\hline \multicolumn{10}{|c|}{ 11-12 months (J20 vs WT) } \\
\hline NM_007393.1 & Actin beta & Actb & 2.30 & 0.033 & NM_008786.1 & $\begin{array}{l}\text { Protein-L-isoaspartate (D-aspartate) } 0 \text { - } \\
\text { methyltransferase } 1\end{array}$ & Pcmt1 & -1.84 & 0.048 \\
\hline NM_198110.1 & $\begin{array}{l}\text { Guanine nucleotide } \\
\text { binding protein-like } 3 \\
\text { (nucleolar)-like }\end{array}$ & Gnl3l & 1.95 & $<0.001$ & NM_009842.3 & CD151 molecule (Raph blood group) & Cd151 & -1.68 & 0.036 \\
\hline NM_001081642.1 & $\begin{array}{l}\text { X-linked lymphocyte- } \\
\text { regulated } 4 \mathrm{~A}\end{array}$ & $X l r 4 a$ & 1.76 & 0.023 & NM_022331.1 & $\begin{array}{l}\text { Homocysteine-inducible, endoplasmic } \\
\text { reticulum stress-inducible, ubiquitin- } \\
\text { like domain member } 1\end{array}$ & Herpud1 & -1.61 & 0.019 \\
\hline NM_145470.2 & $\begin{array}{l}\text { DEP domain } \\
\text { containing MTOR- } \\
\text { interacting protein }\end{array}$ & Deptor & 1.53 & 0.024 & NM_012002.1 & COP9 signalosome subunit 6 & Cops6 & -1.60 & 0.021 \\
\hline NM_133903.2 & $\begin{array}{l}\text { Spondin } 2 \text {, } \\
\text { extracellular matrix } \\
\text { protein }\end{array}$ & Spon2 & 1.51 & 0.016 & NM_183187.2 & $\begin{array}{l}\text { Family with sequence similarity } 107 \text {, } \\
\text { member A }\end{array}$ & Fam107a & -1.58 & 0.014 \\
\hline XM_196324.2 & $\begin{array}{l}\text { Deafness, autosomal } \\
\text { recessive } 31\end{array}$ & Dfnb31 & 1.47 & 0.005 & NM_007472.1 & Aquaporin 1 (Colton blood group) & Aqp1 & -1.52 & 0.028 \\
\hline NM_054071.1 & $\begin{array}{l}\text { Fibroblast growth } \\
\text { factor receptor-like } 1\end{array}$ & Fgfrl1 & 1.47 & 0.012 & NM_008947 & $\begin{array}{l}\text { Proteasome (prosome, macropain) 26S } \\
\text { subunit, ATPase, } 1\end{array}$ & Psmc1 & -1.52 & 0.012 \\
\hline NM_013882.1 & $\begin{array}{l}\text { G-2 and S-phase } \\
\text { expressed } 1\end{array}$ & Gtse1 & 1.46 & 0.004 & NM_008610.1 & $\begin{array}{l}\text { Matrix metallopeptidase } 2 \text { (gelatinase } \\
\text { A) }\end{array}$ & Mmp2 & -1.50 & 0.008 \\
\hline NM_016972.2 & $\begin{array}{l}\text { Solute carrier family } 7 \text {, } \\
\text { member } 8\end{array}$ & Slc7a8 & 1.44 & 0.008 & NM_007413.2 & Adenosine $\mathrm{A} 2 \mathrm{~b}$ receptor & Adora $2 b$ & -1.50 & 0.047 \\
\hline NM_001080126.1 & $\begin{array}{l}\text { Caspase } 8 \text {, apoptosis- } \\
\text { related cysteine } \\
\text { peptidase }\end{array}$ & Casp8 & 1.43 & 0.031 & NM_008504.2 & Granzyme M (lymphocyte metase 1) & Gzmm & -1.49 & 0.003 \\
\hline
\end{tabular}


performed, the fold-changes in gene expression are small and varied to a maximum fold-increase of 3.01 and fold-decrease of 3.45 (Table 1 and Supplementary Tables 1 and 2).

\subsection{The pattern of changes in the CP transcriptome of J20 mice varied with age}

Using the gene network analysis computed by the IPA software, we were able to establish a list of the 5 most altered gene networks, and associated biological functions, at each age in the $\mathrm{CP}$ of J20 mice (Fig. 2A-F). Of notice, this analysis revealed that the most altered gene network is different at each age (Fig. 2B, D and F). At 3 months, at least two of the altered gene networks were involved in the regulation of one of the following biological functions: molecular transport, metabolism of small molecules, cell-to-cell signaling/endocrine system function and cell death/survival (Fig. 2A). At 5-6 months of age, in addition to the alterations in the genes of network 5 (Fig. 2C) already affected at 3 months (Fig. 2A), the main biological functions and processes found to be altered were related with the hematological system, inflammatory and humoral immune responses and cellular morphology and motility (gene networks 1-4, Fig. 2C). Of notice, those alterations in inflammation/immune-related pathways at 56 months were sustained at 11-12 months, since the most altered gene network in the $\mathrm{CP}$ of 11-12 months-old J20 mice regulated the inflammatory and antimicrobial responses (gene network 1, Fig. 2E) and included, as central modulators, the genes interferon beta 1 (Ifnb1) and signal transducer and activator of transcription 1 (Stat1) (Fig. 2F). The gene networks 2-5, affected at 1112 months, showed again alterations in processes such as small molecule biochemistry, molecular transport and cellular signaling, movement and survival (Fig. 2E).

\subsection{Type I and II IFN responses were altered in the CP of J20 mice}

Taking into account the previous alterations, particularly those regarding gene pathways involved in the regulation of the inflammatory/immune responses in the $\mathrm{CP}$ of $\mathrm{J} 20$, we next pursued the underlying transcriptional regulators that could be responsible for such alterations in gene expression (Fig. 3 and Supplementary Table 3). For that analysis, we used the IPA Upstream Regulator application, that computed an activation $z$-score predictive of the activation status of a given transcriptional regulator, taking into account the expression level of the corresponding downstream target genes in the $\mathrm{CP}$ of $\mathrm{J} 20$ mice at each age (Fig. 3A). Using the five regulators with highest $z$-score and the five regulators with lowest $z$-score (Supplementary Table 3), this analysis allowed the assembly of gene interactomes (Fig. 3B-D). At 3 months, this approach discriminated the genes Toll-like receptor 9 (Tlr9), interferon regulatory factor 7 (Irf7) and interferon (alpha and beta) receptor 1
(Ifnar1), all of them predicted to be up-regulated in the CP of J20 mice, when compared with age matched WT mice (Fig. 3A and B). Surprisingly, at the ages of 5-6 and 11-12 months, interferon gamma (Ifng) presented a low activation $z$-score that suggested a possible down-regulation of this gene in the CP of J20 mice (Fig. 3A, C and D). Noticeably, the inactivation of the Ifng-regulated pathway was predicted to affect the expression of 18 target genes at 5-6 months (Fig. 3C and Supplementary Table 3), an effect that was even more marked at 11-12 months, affecting 25 downstream genes/molecules (Fig. 3D and Supplementary Table 3).

To confirm and complement the array data, the expression of type I IFN-related genes [Tlr9, Ifnar1, Irf7, interferon alpha 1 (Ifna1) and interferon beta 1 (Ifnb1)] and of type II IFN-related genes [Ifng and intercellular adhesion molecule 1 (Icam1)] was measured by qRT-PCR (Fig. 4A-G). Once again, we observed an overexpression of Tlr9, Ifnar1, Irf7 and Ifnb1, in the CP of J20 mice at 3 months, when compared with WT mice; together with Ifna1, these genes remained highly expressed in the CP of J20 mice at 5-6 months when compared to 3 months-old WT mice (Fig. 4AE). In the CP of WT mice, despite the unaltered expression of Irf7, Ifna and Ifnb1 (Fig. 4C-E) at different ages, we observed a significant overexpression of Tlr9 and Ifnar1 at 11-12 months, when compared to the 3 months-old mice of the same genotype (Fig. 4A and B). The genes Ifng and Icam1, which are related with a type II IFN response, were also significantly overexpressed at 3 months in the $\mathrm{CP}$ of $\mathrm{J} 20$ mice, when compared to age-matched WT mice (Fig. 4F and G). On the other hand, at 5-6 months, there was a significant down-regulation of Ifng in the CP of J20 mice, when compared to the expression levels at 3 months in J20 and at 5-6 months in WT mice, which was maintained at 1112 months (Fig. 4F).

Next, to discriminate the specific contribution of CP epithelial cells to the expression of type I or type II IFN genes in AD, we performed primary cultures of CP epithelial cells on a transwell system (to mimic the in vivo tight and polarized arrangement that these epithelial cells present in the blood-CSF barrier, Fig. $4 \mathrm{H}$ ), and stimulated these cells at the apical membrane, which mimics the CSF-side, with $1 \mu \mathrm{M} \mathrm{A} \beta_{1-42}$. We observed that in response to $A \beta_{1-42}$, the $C P$ epithelial cells significantly overexpressed the type I IFN genes Tlr9 and Ifna1, but not the type II IFN gene Ifng (Fig. 5I-K).

\subsection{Aging altered the pattern of type I and II IFN gene expression in the dHPC of WT and of J20 mice}

To further investigate the IFN response at the brain parenchyma, we measured the expression of the same type I and II IFN genes in the dHPC of WT and J20 mice at different ages (Fig. 5A$\mathrm{G})$. As observed before in the $\mathrm{CP}$ of $\mathrm{J} 20$ mice, there was an

Table 2

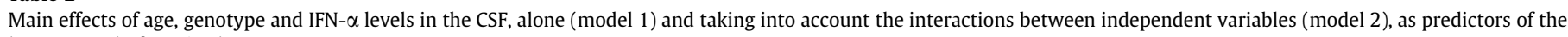
latency to platform in the MWM test.

\begin{tabular}{|c|c|c|c|c|c|c|}
\hline \multirow[t]{2}{*}{ Independent variables and interactions } & \multicolumn{3}{|c|}{ Latency (model 1) } & \multicolumn{3}{|c|}{ Latency (model 2) } \\
\hline & $\beta$ & $p$ & $R^{2}$ (adjusted) & $\beta$ & $p$ & $R^{2}$ (adjusted) \\
\hline Age & 2.5840 & 0.3372 & 0.6712 & 1.7302 & 0.5006 & 0.7177 \\
\hline Genotype & 36.853 & $<0.0001$ & & 35.962 & $<0.0001$ & \\
\hline IFN- $\alpha$ & 0.8746 & 0.0087 & & 0.4878 & 0.2056 & \\
\hline Age*Genotype & \multirow{4}{*}{\multicolumn{3}{|c|}{ Not included }} & -15.595 & 0.0038 & \\
\hline Age*IFN- $\alpha$ & & & & -0.0957 & 0.8435 & \\
\hline Genotype*IFN- $\alpha$ & & & & -0.2905 & 0.7038 & \\
\hline Age $^{*}$ Genotype*IFN- $\alpha$ & & & & 0.3214 & 0.7405 & \\
\hline
\end{tabular}

WT mice: $N$ (3 months $)=12 ; N(5-6$ months $)=7 ; N(11-12$ months $)=9$.

J20 mice: $N(3$ months $)=5 ; N(5-6$ months $)=9 ; N(11-12$ months $)=8$.

No collinearity was observed between independent variables. 
A Gene expression alterations in 3 months-old J20 mice (normalized to 3 months-old WT mice)

\begin{tabular}{|c|c|c|c|}
\hline Top 5 Netv & Number of genes & Up-regulated molecules & Down-regulated molecules \\
\hline $\begin{array}{l}1 \text { Endocrine System } \\
\text { Development and Function, } \\
\text { Molecular Transport, Small } \\
\text { Molecule Biochemistry }\end{array}$ & $9 \uparrow 20 \downarrow$ & $\begin{array}{l}\text { HTR2C, II3, LIPE, NKX2-2, NR3C1, } \\
\text { RUNX2, SIRT6, SMARCC1, SS18L1 }\end{array}$ & $\begin{array}{l}\text { ABCC8, ACADL, C5, CCR4, CD798, } \\
\text { CTSE, DOK1, ERK HMGA1, Ins1, } \\
\text { ITGB1BP2, MAPK12, Ms4aAb(includes } \\
\text { others), PASK, PrI3d1 (includes others), } \\
\text { SLC38A1, SLC6A19, TBC1D4, TRIB3, } \\
\text { TSC22D3 }\end{array}$ \\
\hline $\begin{array}{l}2 \text { Cell Death and Survival, } \\
\text { Organismal Development, } \\
\text { Cellular Development }\end{array}$ & $9 \uparrow 17 \downarrow$ & $\begin{array}{l}\text { AP2A1, DSG1, ISG15, MED1, MST 1R, } \\
\text { SCGB1A1, TFRC, TNFSF12, USP18 }\end{array}$ & $\begin{array}{l}\text { BBC3, CFD, DLG1, HOXA9, ICOS, } \\
\text { IL2RB, KDR, Map3K7, PER2, PFN1, } \\
\text { PLCG1, RPSA SKP2, STAMM2, TBX21, } \\
\text { TNFAIP\&L2, UCP1 }\end{array}$ \\
\hline $\begin{array}{l}3 \text { Organismal Injury and } \\
\text { Abnormalities, Cell-Ta-Cell } \\
\text { Signaling and Interaction, } \\
\text { Small Molecule Biochemistry }\end{array}$ & $9 \uparrow 9 \downarrow$ & $\begin{array}{l}\text { ABLIM1, ABR, CYBRD1, DENND2D, } \\
\text { GPC4, IPCEF1, LGI1, PRSS2, WISP1 }\end{array}$ & $\begin{array}{l}\text { CANT1, CPNET, HIST 1H 1T, HTR2A, } \\
\text { MAST1, RCN1, STOM, TEAD1, } \\
\text { TFAP2B }\end{array}$ \\
\hline $\begin{array}{l}4 \text { Cell Death and Survival, } \\
\text { Connective Tissue Disorders, } \\
\text { Hematological Disease }\end{array}$ & $7 \uparrow 10 \downarrow$ & $\begin{array}{l}\text { ACSM3, CELA3B, Cyp2j5, KIFC2, } \\
\text { KLK3, SIco1a1, TM4SF4 }\end{array}$ & $\begin{array}{l}\text { AOX1, ATF7, C5, C8A, ELOVL4, } \\
\text { GOLT1A, KNG1, TBX21, TMED6, } \\
\text { UGT2B7 }\end{array}$ \\
\hline $\begin{array}{l}5 \text { Carbohydrate Metabolism, } \\
\text { Molecular Transport, Small } \\
\text { Molecule Biochemistry }\end{array}$ & $9 \uparrow 8 \downarrow$ & $\begin{array}{l}\text { APBB3, CPSF1, EPB41L2, MBD1, } \\
\text { OTOF, RAPGEF1, SIRT6, TFAP2C, } \\
\text { TMCC2 }\end{array}$ & $\begin{array}{l}\text { ACADL, ARL2BP, AUTS2, CRAT, } \\
\text { NEU2, Olfr1107, SKP2, ST18 }\end{array}$ \\
\hline
\end{tabular}

\section{Gene expression alterations in 5-6 months-old J20 mice} (normalized to 5-6 months-old WT mice)

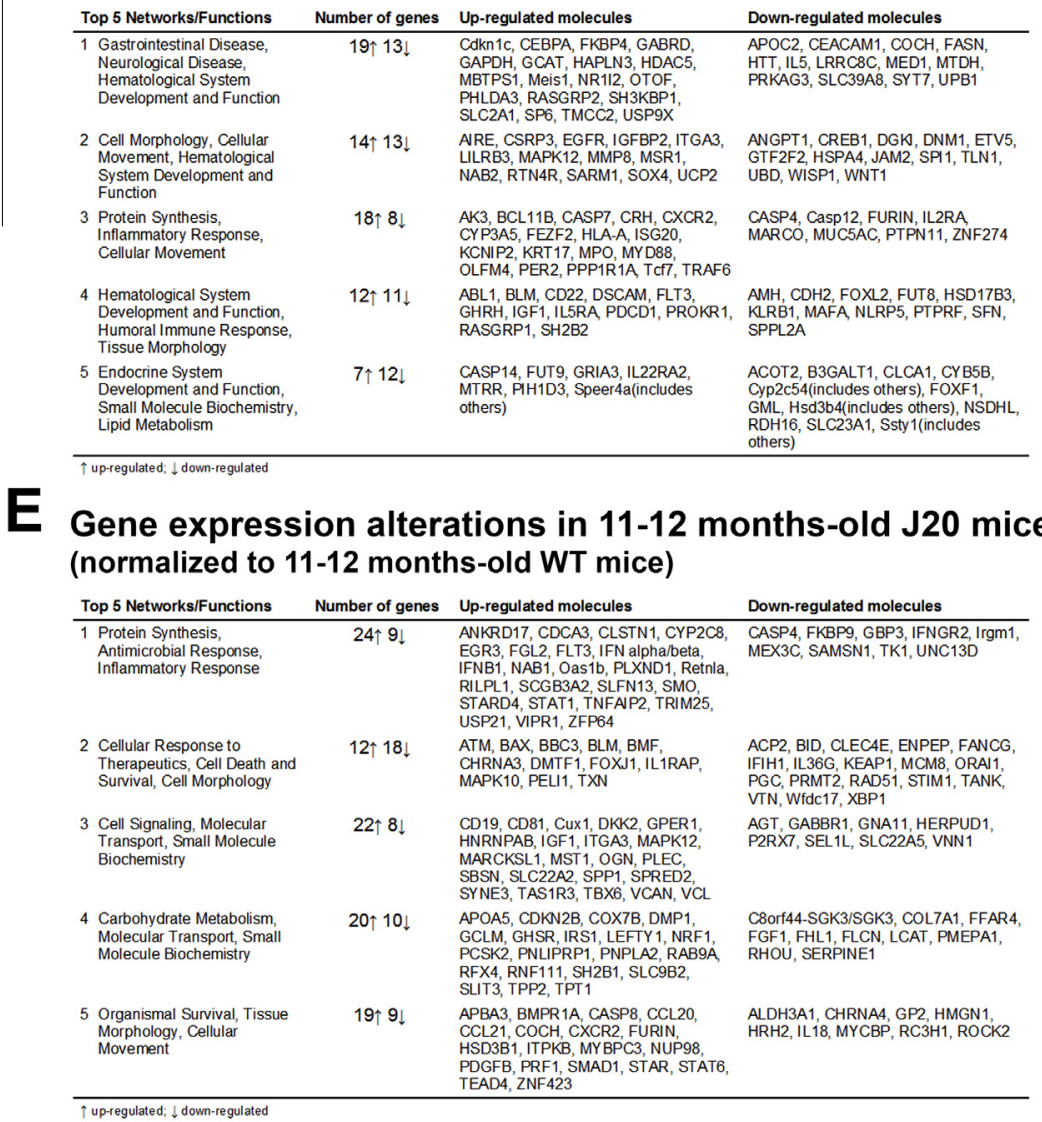

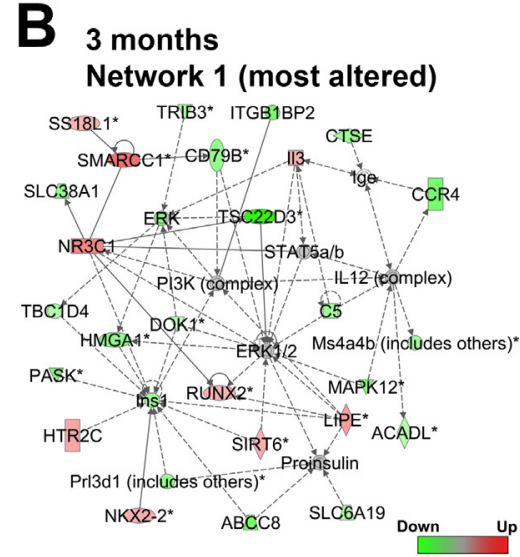

\section{D-6 months Network 1 (most altered)}

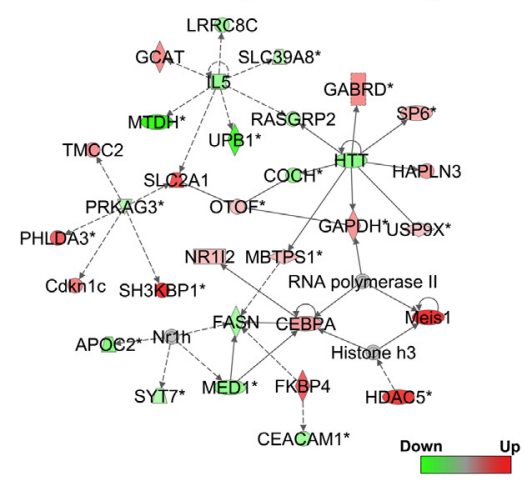

\section{F 11-12 months Network 1 (most altered)}

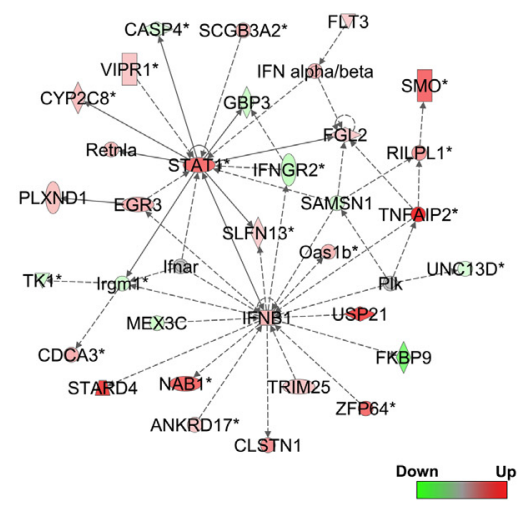

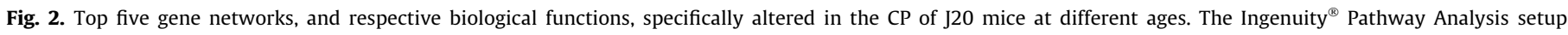

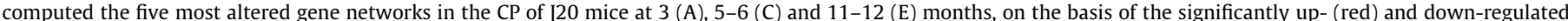

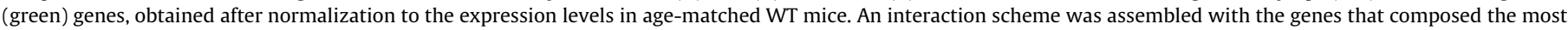
altered network in the CP of J20 mice at 3 (B), 5-6 (D) and 11-12 (F) months.

overexpression of type I IFN genes in the dHPC of J20 mice at 3 months, when compared to age-matched WT mice, that was statistically significant for Tlr9, Ifna1 and Ifnb1 (Fig. 5A, D and E). Additionally, we observed a progressive increase in the expression of all type I IFN genes, with aging, in the dHPC of WT mice, which was statistically significant at 11-12 months, when compared to the expression levels of WT mice at 3 months (Fig. 5A-E). Regarding the expression of type II IFN genes in the dHPC (Fig. $5 \mathrm{~F}$ and $\mathrm{G}$ ), even though there was an increased expression of Icam 1 in 11-12 months-old WT mice (Fig. 5G), no changes were observed on the levels of Ifng expression at the different ages (Fig. 5F).

In an attempt to unravel the specific contribution of different brain cell populations to the overexpression of type I and II IFN genes, we measured the expression of Tlr9, Ifna1 and Ifng in primary cultures of astrocytes and of neurons, at different time points upon stimulation with vehicle or $1 \mu \mathrm{M} \mathrm{A} \beta_{1-42}$. However, no statistical significant differences were observed when comparing 
A

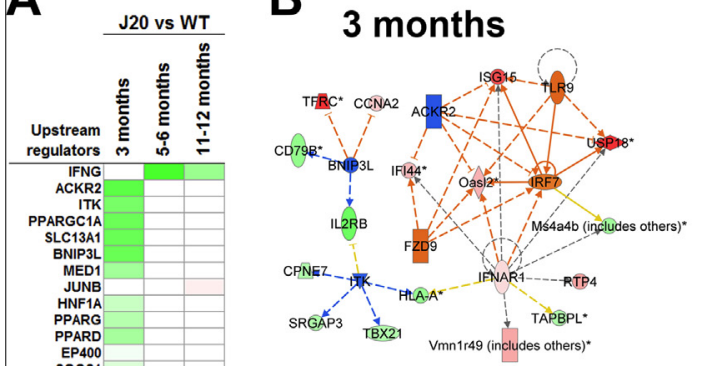

\section{5-6 months}

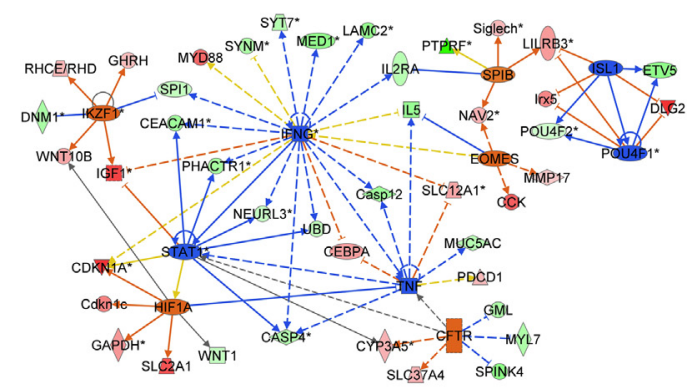

D $11-12$ months
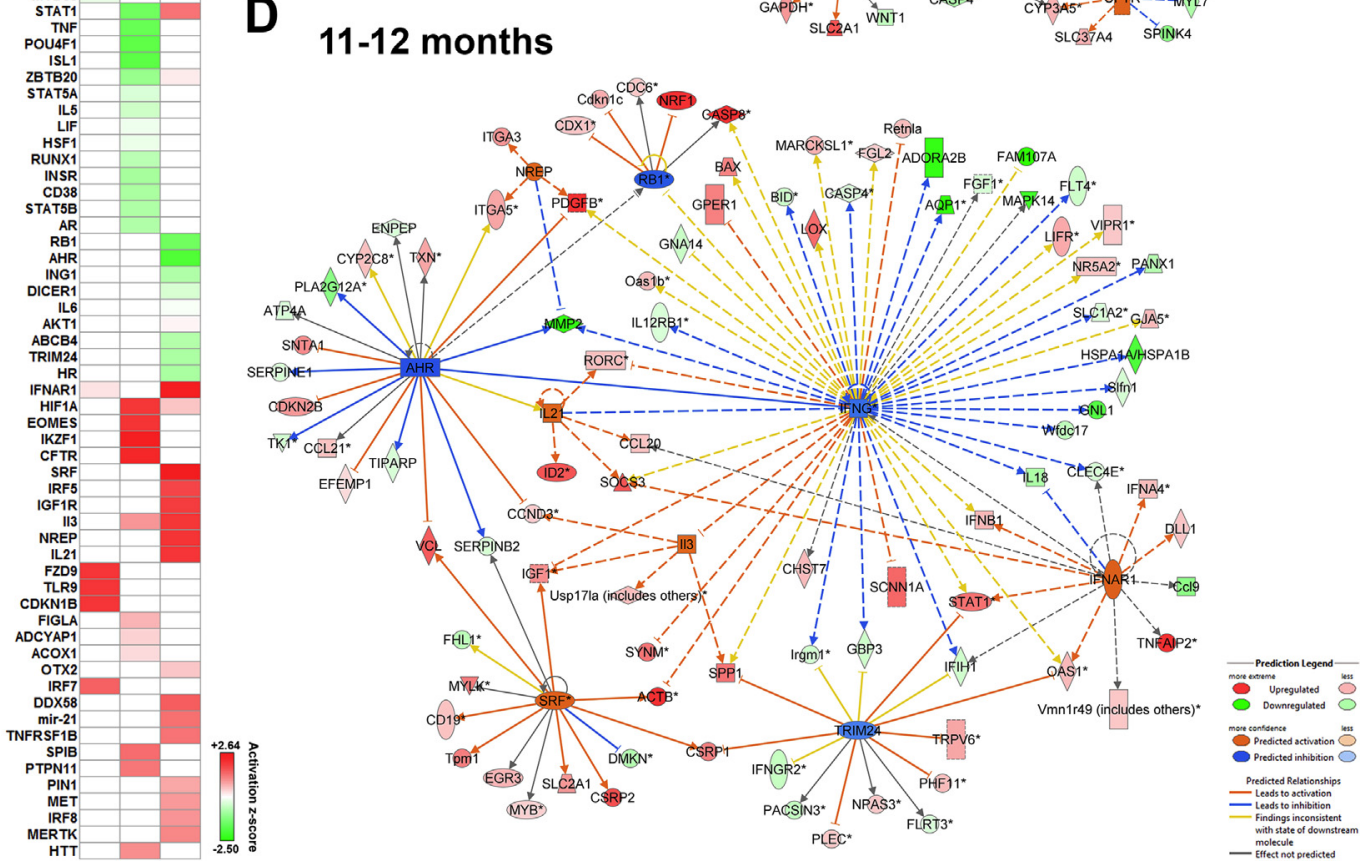

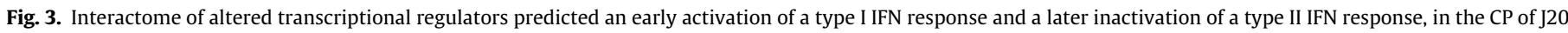

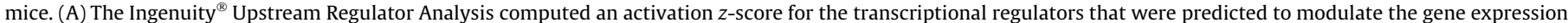

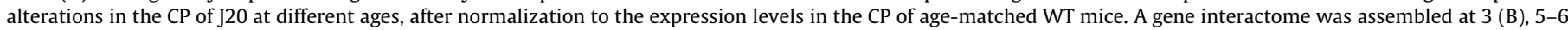

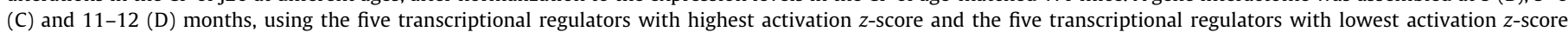

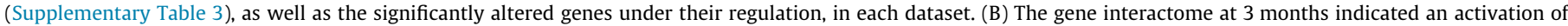

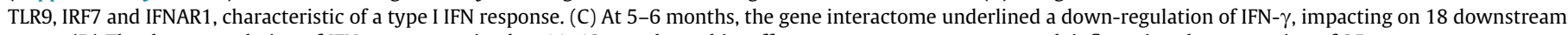
genes. (D) The down-regulation of IFN- $\gamma$ was sustained at 11-12 months and its effect was even more pronounced, influencing the expression of 25 target genes.

vehicle- or $A \beta_{1-42}$-treated cells at 24 and $72 \mathrm{~h}$ (Supplementary Fig. 4).

\subsection{Early activation of astrocytes and microglia was observed in the} dHPC of $J 20$ mice

To have a different readout of the inflammatory response in the dHPC of WT and J20 mice at different ages, we measured the expression of Gfap and Iba1, as well as the morphology of astrocytes and the number of microglia/macrophages from the DG of the dHPC, based on the staining for GFAP and IBA1, respectively (Fig. 5H-K). There was a significant overexpression of Gfap and Iba1 in the dHPC of J20 mice, at 3 months, when compared to the expression levels in age-matched WT mice (Fig. $5 \mathrm{H}$ and $\mathrm{J}$ ). The expression of Gfap was also significantly increased in the dHPC of WT mice at 11-12 months (Fig. 5H). Regarding the morphological characterization of astrocytes, overall, we observed that astrocytes from the dHPC of J20 mice presented a more ramified phenotype at 3 months, whereas, in the WT mice, these morphological alterations were observed at the age of 5-6 months (Fig. 5I). In that sense, except for the number of processes, a significant increase in the values of the analyzed astrocytic morphological parameters (length of individual processes, total surface and number of endings) was observed in astrocytes from the DG of J20 mice at 3 months, when compared to 3 months-old WT mice and to 56 months-old J20 mice (Fig. 5I). Noticeably, at 5-6 months, the astrocytes from the DG of WT mice presented more processes and were larger and more ramified than those of 5-6 months-old J20 mice and of 3 months- and 11-12 months-old mice of the same genotype (Fig. 5I). Concerning the quantification of microglia/macrophages, there was a significant increase in the number of IBA $1^{+}$cells per $\mathrm{mm}^{2}$ in the DG of the dHPC of $\mathrm{J} 20$ mice at 1112 months, when compared to all other groups (Fig. 5K).

\subsection{Increased level of IFN- $\alpha$ in the CSF was correlated with a worst performance in the MWM}

The level of IFN- $\alpha$ was measured in the CSF of WT and J20 mice, at different ages (Fig. 6A). Although not significant, we observed a tendency for an increased level of IFN- $\alpha$ in the CSF of J20 mice, when compared to 3 months-old WT mice, which was sustained over time (Fig. 6A). Interestingly, we observed a significant increase in the level of IFN- $\alpha$ in the CSF of WT mice at 5-6 and at 11-12 months, when compared to 3 months-old WT mice 


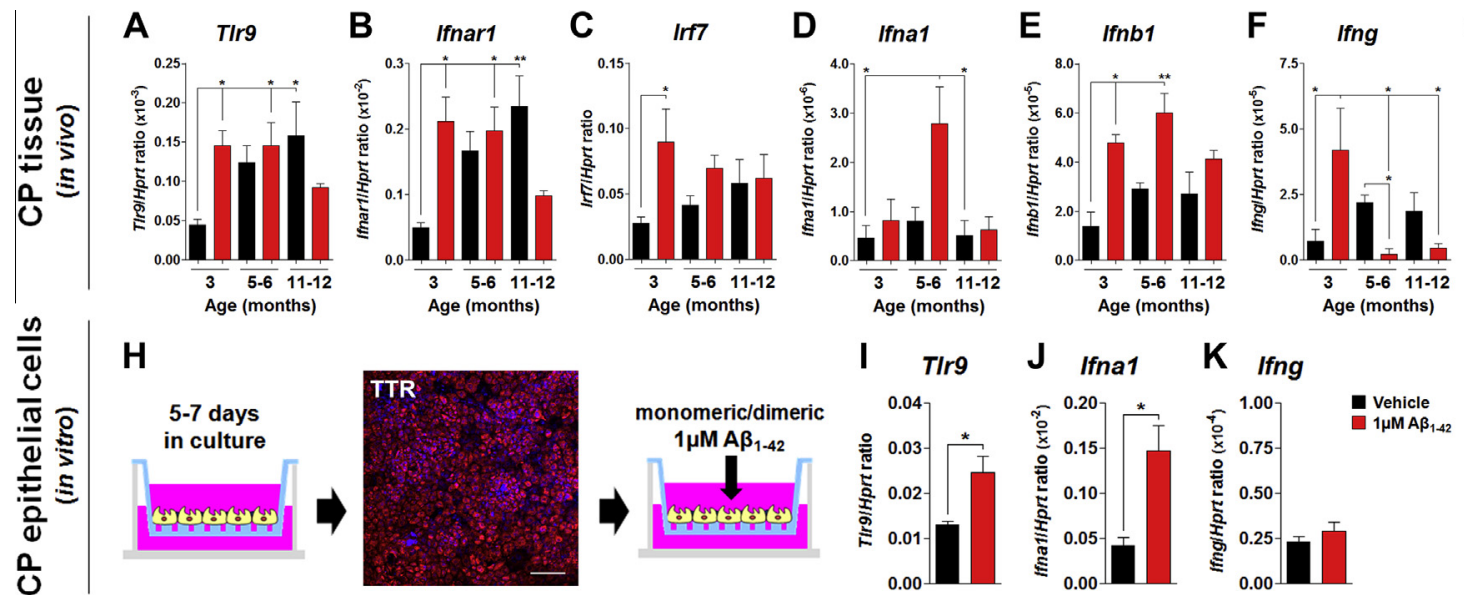

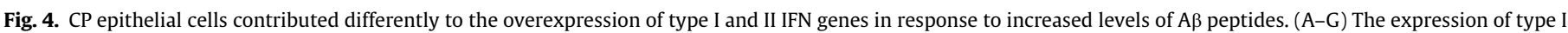

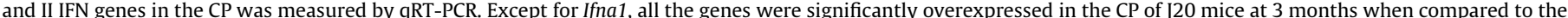

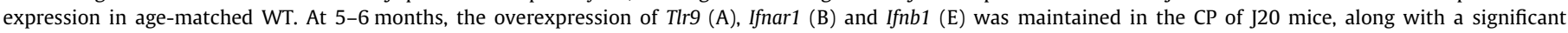

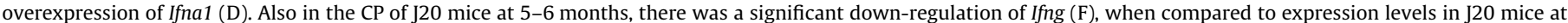

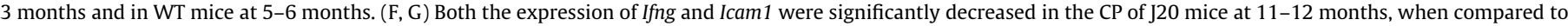

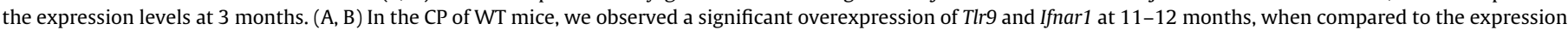

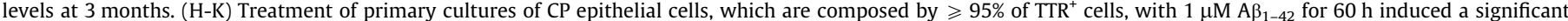

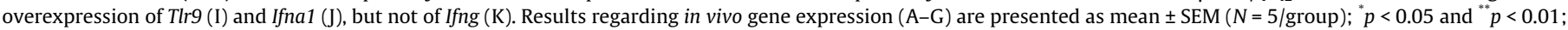

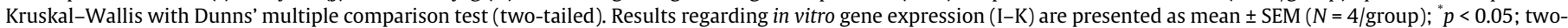
tailed Mann Whitney test. Scale bar indicates $100 \mu \mathrm{m}$ in $(\mathrm{H})$.

(Fig. 6A), which was positively correlated with an increased time to find the hidden platform in the MWM (calculated as the average time of latency to platform in the five days of the test) (Fig. 6B). However, no significant correlations were observed between the levels of IFN- $\alpha$ and the latency to platform, when analyzing mice at each age separately (Supplementary Fig. 5).

In order to analyze the effects of age, genotype and IFN- $\alpha$ levels in the CSF as predictors of the spatial-reference memory performance, we designed two regression models, to take into consideration the main effects of the independent variables alone or all the possible interactions (Table 2). The genotype and the levels of IFN- $\alpha$ in the CSF, alone, were significantly associated with alterations in the performance in the MWM (model 1, Table 2). However, when the interactions between the independent variables were considered, the genotype significantly moderated the relation between age and latency (model 2, Table 2). Of relevance, when comparing the two models, the inclusion of the interaction effects only represented an increment of $4.65 \%$ in the explained variance of latency which was of $67.12 \%$ when no interactions were included in the analysis.

\section{Discussion}

A progressive dysfunction of the blood-CSF barrier, which is formed by the CP epithelial cells, is described in AD (Johanson et al., 2004; Marques et al., 2013; Serot et al., 2012). To better understand the specific alterations that occur at this barrier, we used the J20 mouse model of AD (Baron et al., 2014; Mucke et al., 2000) and investigated the changes in the CP transcriptome at the ages of 3, 5-6 and 11-12 months, in comparison with age-matched WT mice. We observed aging-induced alterations in the $\mathrm{CP}$ transcriptome involving gene networks that regulate central processes, such as the cellular circadian rhythm (Zhang and Kay, 2010), which are likely to affect the metabolic activity and cytoarchitecture of the blood-CSF barrier and to contribute to a defective turnover of the CSF (He et al., 2014; Serot et al., 2012).

Regarding the CP of J20 mice, there was a sustained overexpression of genes that participate in the type I IFN response and a clear decrease in the expression of Ifng, the major type II IFN gene. In a later age, but following the same direction, the $\mathrm{CP}$ of WT mice displayed an aging-associated increased expression of genes that encode for two receptors that are involved in the type I IFN response, Tlr9 and Ifnar1, but no significant alterations in the expression of genes involved in the type II IFN response. Interestingly, the specific contribution of $\mathrm{CP}$ epithelial cells to the overexpression of type I IFN genes, but not of the type II IFN gene Ifng, shown to occur in vitro in response to $A \beta$, led us to suggest that the early overexpression of Ifng in the CP of J20 mice is due to immune-related cells that inhabit and circulate in the CP stromal compartment, a subject that warrants further investigation. Interestingly, the strong activation of the type I IFN response both in the CP and in the dHPC of J20 mice in early phases of the disease, before marked amyloid deposition, together with the decreased expression of Ifng in the CP at 5-6 and at 11-12 months, suggest a possible interplay between type I and II IFN responses and $A \beta$ plaque formation. Moreover, although there is an apparent relationship between the up-regulation of type I IFN genes, the early overexpression of Gfap and Iba1 and increased astrocytic branching in the dHPC, occurring first in J20 and later in WT mice, it is still unclear whether these observations are somehow connected. Of notice, together with a lower expression of type I IFN genes a decreased branching of astrocytes and increased number of microglia/macrophages was also found in the DG of the dHPC of J20 mice at 11-12 months. Intriguingly, also at 11-12 months, along with a decreased inflammatory gene expression in the dHPC, the behavioral impairment of J20 mice seems to become milder, when compared to 3 months-old mice of the same genotype. Once again, whether there is a causal relationship between these events in the brain of J20 mice and the deficits in memory is something that needs to be addressed in the future. In addition, an age-dependent increased level of IFN- $\alpha$ in the CSF, observed only in WT mice, is correlated with a poor performance in a spatial reference-memory task. On the other hand, the J20 mice presented no significant alterations in the level of IFN- $\alpha$ in the CSF, which is in agreement with their early and sustained memory impairment. In fact, it is still controversial whether an early induction of a type I IFN inflammatory response in the brain, followed by a reduced type II IFN response, is beneficial or detrimental for $\mathrm{AD}$ 

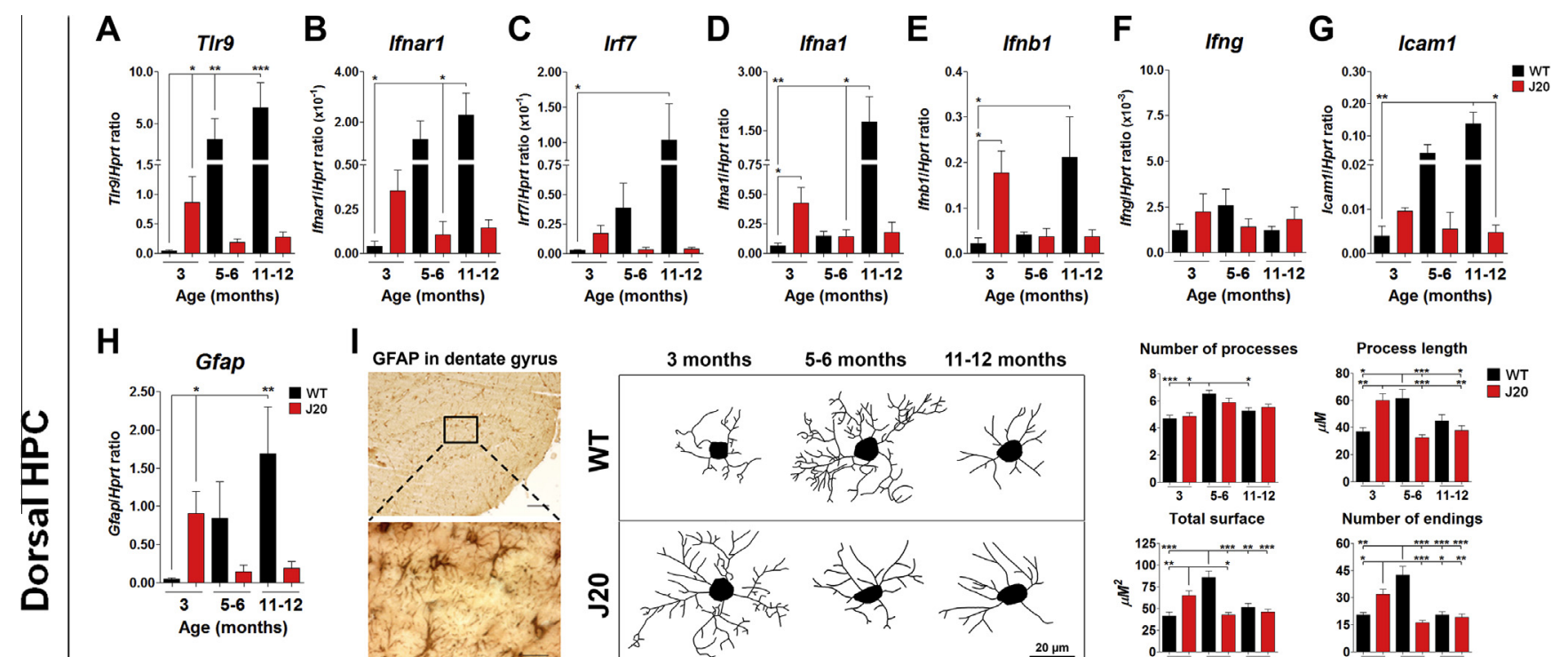

I GFAP in dentate gyrus
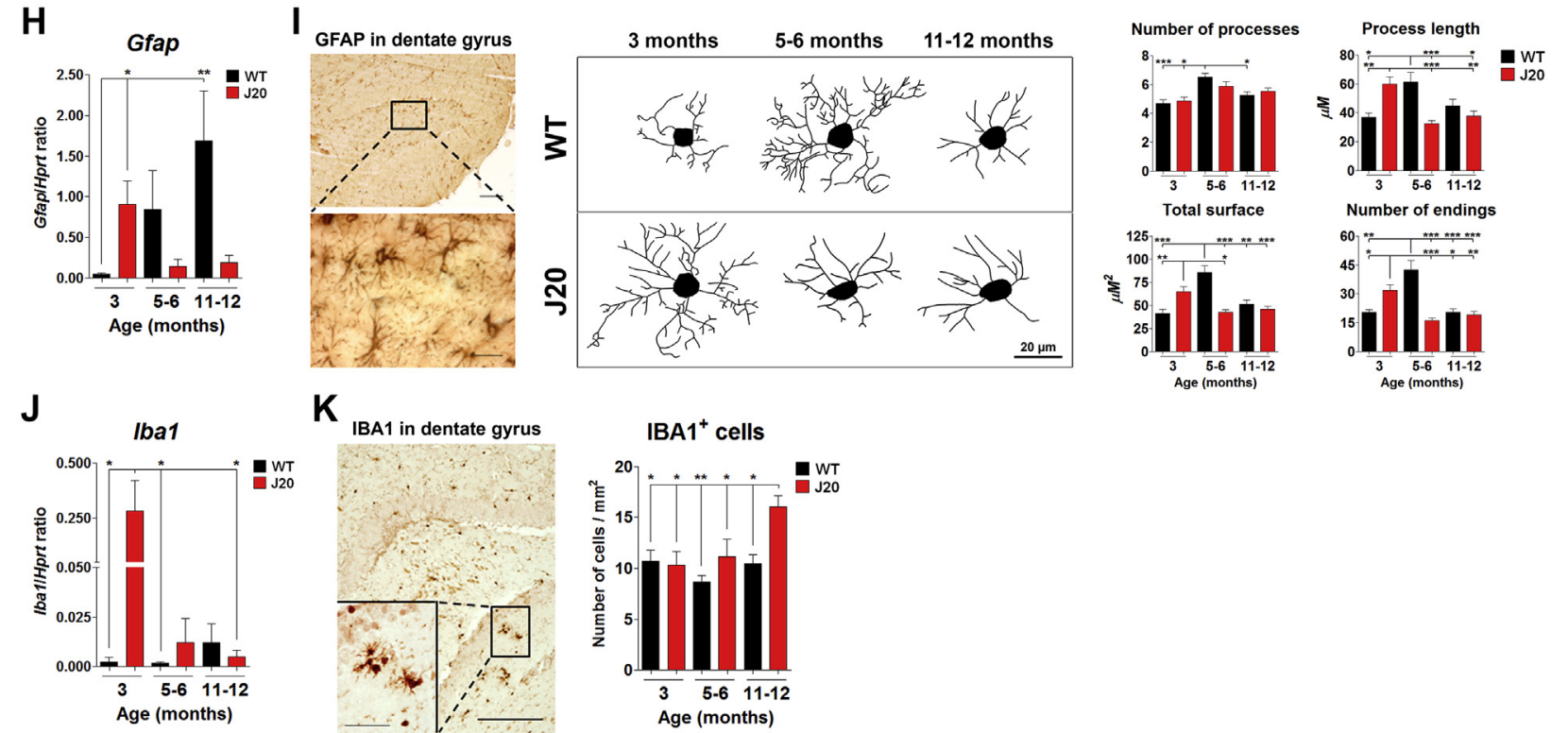

K

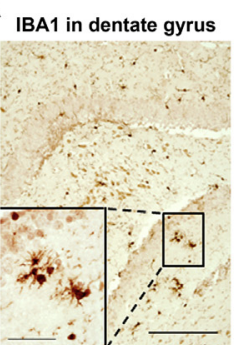

IBA1 $^{+}$cells

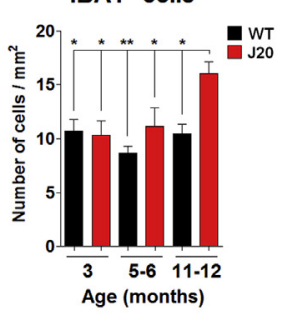

Fig. 5. Aging altered the pattern of type I and II IFN gene expression, the morphology of astrocytes and the number of microglia/macrophages in the dHPC of WT and J20 mice. (A-G) The expression of type I and II IFN genes in the dHPC was measured by qRT-PCR. A significant overexpression of the type I IFN genes Tlr9 (A), Ifna1 (D) and Ifnb1 (E) was observed in the dHPC of J20 mice at 3 months. On the other hand, at 11-12 months, except for Ifng (F), there was a statistically significant overexpression of all genes in the dHPC of WT mice. (H, I) To correlate the type I IFN gene expression with a different readout of the inflammatory status in the dHPC, the expression of Gfap and the morphology of astrocytes was analyzed in the DG. (H) There was a significant overexpression of Gfap in the dHPC of J20 and WT mice, at 3 and 11-12 months, respectively. (I) A significant increase in the size and number of endings of the astrocytic processes and, consequently, in the total surface of astrocytes, was observed in the DG of the dHPC of J20 mice at 3 months. In contrast, at 5-6 months and 11-12 months, the astrocytes of the DG of J20 mice presented less ramified processes and occupied a smaller surface. Noticeably, the astrocytes from the DG of WT mice presented a significant increase in all the analyzed morphological parameters at 5-6 months, but became significantly smaller and less ramified at 11-12 months. (J) There was a significant overexpression of $I b a 1$ in the dHPC of J20 mice at 3 months. (K) The number of IBA $1^{+}$cells per mm ${ }^{2}$ in the DG of $11-$ 12 months-old 20 mice was significantly higher when compared to all other groups. Results regarding gene expression are presented as mean \pm SEM $(N=5 /$ group); $" p<0.05$, $" p<0.01$ and ${ }^{* * * *} p<0.001$; Kruskal-Wallis with Dunns' multiple comparison test (two-tailed). Results regarding astrocytic morphology in (I) are presented as mean \pm SEM $(N=30$ astrocytes/group) and microglia/macrophages in (K) are presented as mean \pm SEM ( $N=4 /$ group at 3 and $5-6$ months, and $N=5 /$ group at $11-12$ months); $" p<0.05$, $" p<0.01$ and " $p<0.001$; Kruskal-Wallis with Dunns' multiple comparison test (two-tailed). Scale bars indicate $100 \mu \mathrm{m}$ (lower magnification) and $20 \mu \mathrm{m}$ (higher magnification) in (I) and $200 \mu \mathrm{m}$ (lower magnification) and $50 \mu \mathrm{m}$ (higher magnification) in (K).

pathogenesis (Baruch et al., 2014; Scholtzova et al., 2009, 2014; Taylor et al., 2014). Regarding the type II IFN response in AD, it has been previously shown that overexpression of IFN- $\gamma$ boosts the amyloidogenic processing of APP both in vitro and in vivo (Blasko et al., 1999; Mastrangelo et al., 2009). In accordance, it was recently suggested that a higher frequency of IFN- $\gamma$-producing T-cells in the brain of AD transgenic mice is associated with increased glial activation and amyloid plaque formation, as well as with worst cognitive function (Browne et al., 2013). However, there is also evidence of a beneficial impact of increased levels of IFN- $\gamma$-producing T-cells in AD transgenic mice at 9 months of age, namely by increased microglial activation, increased $A \beta$ phagocytosis and decreased plaque burden in the DG of the HPC (Monsonego et al., 2006). These divergent observations may be due to the specific effects of IFN- $\gamma$ overproduction at different stages of brain pathology in $\mathrm{AD}$, which prompts for a deeper characterization of the role of the type II IFN mediators in the $\mathrm{AD}$ brain at different ages. On the other hand, concerning the type I IFN response, a recent study showed that at the level of the $\mathrm{CP}$ of 22 months-old mice, increased levels of IFN- $\beta$ signaling promote increased glial activation and impact on cognitive behavior (Baruch et al., 2014). Moreover, it was suggested that an aging-related central nervous system (CNS)-derived stimulus could be in the genesis of a shift from a type II IFN into a type I IFN response at the $\mathrm{CP}$, and that this would compromise the immune-surveillance of the brain by decreasing the levels of IFN- $\gamma$ (Baruch et al., 2014; Kunis et al., 2013). Interestingly, even in the absence of a viral infection, increased levels of type I IFN cytokines in the brain, particularly IFN- $\alpha$, lead to massive encephalopathy, with marked meningoencephalitis, calcium mineralization, gliosis, and neurodegeneration (Akwa et al., 1998). In the context of $\mathrm{AD}$, others have shown that the genes encoding for IFN- $\alpha$ and IFN- $\beta$ are overexpressed in cultured neurons, upon stimulation with $A \beta$, and in cortical cells extracted from the brains of AD patients, in a mechanism dependent on IRF7 and IFNAR1, which is associated with decreased neuronal viability (Taylor et al., 2014). Conversely, stimulation of the innate response with the TLR9 agonists cytosine-guanosine-containing DNA oligodeoxynucleotides (CpG DNA oligos), in two different mouse models of $\mathrm{AD}$, ameliorated both the pathologic hallmarks and the 
A

\section{IFN- $\alpha$ in CSF}

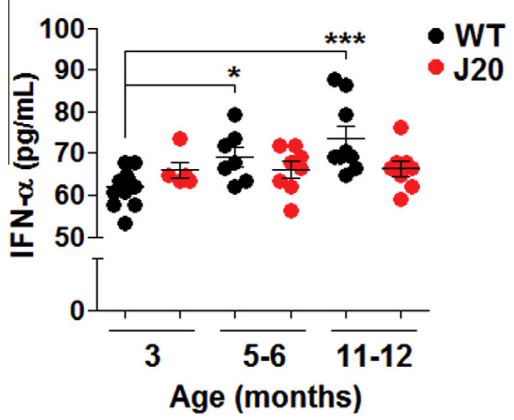

B

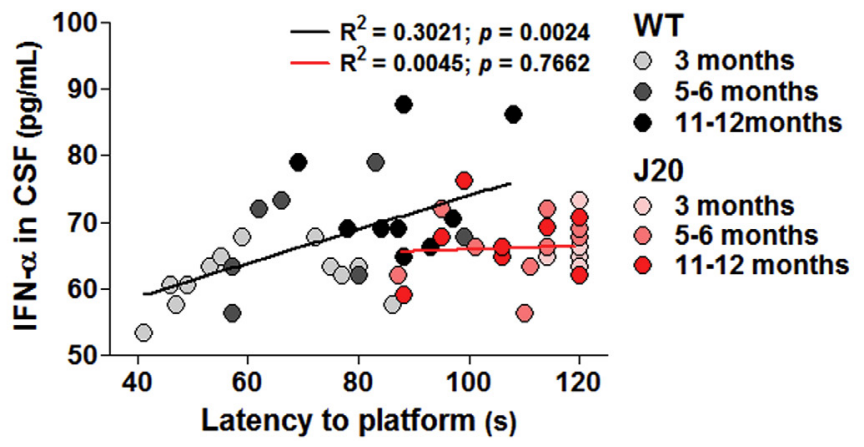

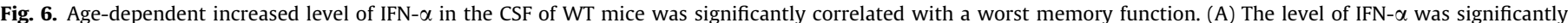

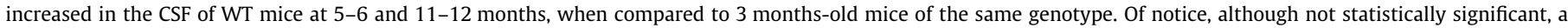

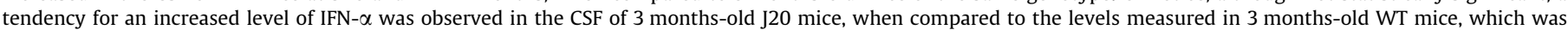

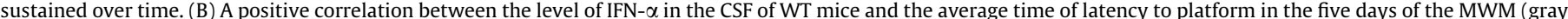

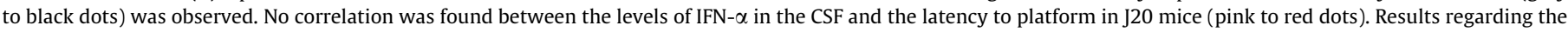

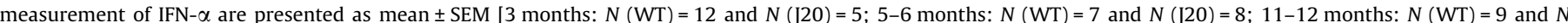

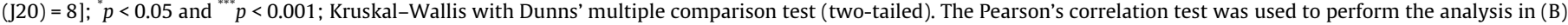
and to calculate the associated $R^{2}$ and $p$-value (two-tailed). Correlation was considered significant for $p<0.05 ; N(\mathrm{WT})=28$ and $N(\mathrm{~J} 20)=22$.

cognitive deficits presented by these mice, without any obvious inflammatory side-effects (Scholtzova et al., 2009, 2014). Also, increased production of IFN- $\beta$ by astrocytes, upon specific TLR3 stimulation, was shown to affect the spontaneous activity of neurons from the CA1 region of the HPC. This effect of IFN- $\beta$ on neuronal excitability was shown to be mediated by IFNAR1, due to the lack of changes in the HPC of Ifnra1-null mice (Costello and Lynch, 2013). Additionally, 9 months-old transgenic APP/PS1 mice present higher levels of IFN- $\alpha$ in the brain, when compared to age-matched WT mice (Taylor et al., 2014). Interestingly, our results also suggest that, along with a possible impact on behavior, an activation of a type I IFN response in the dHPC, in younger J20 mice and in 11-12 months-old WT mice may be linked with changes in the astrocytes' morphology. It is widely accepted that increased levels of inflammatory molecules, whether in the circulation or in specific regions of the CNS, can affect the morphology and function of brain cells, especially of glial cells (Baron et al., 2014; Ghosh et al., 2013). Astrocytes in particular seem to play a central role in the inflammatory response and are good indicators of the level of brain inflammation (Medeiros and LaFerla, 2013; Wyss-Coray, 2006). Concurrently, the activation of astrocytes and microglia was shown to occur before $A \beta$ plaque formation in the HPC of 20 mice (Baron et al., 2014; Beauquis et al., 2014; Wright et al., 2013) and that an increased microglial activation and clustering, observed at 4 weeks of age in the HPC of these mice, precedes neuronal atrophy, decreased neurogenesis and a decrease in the volume of the HPC (Fu et al., 2014). However, it is necessary to further investigate whether the early induction of type I IFN genes in the dHPC of J20 mice is directly promoting changes in glial activation and $A \beta$ pathology. Moreover, it will be important to explore the impact of increased level of type I IFN cytokines, such as IFN- $\alpha$, on the premature memory deficits observed in this AD mouse model and on the memory and cognitive impairments in older WT mice.

Overall, this study reveals that structures such as the $\mathrm{CP}$ and the dHPC may be key elements in the inflammatory signaling in the CNS, by modulating the levels of IFNs, with a possible impact on memory and cognition.

\section{Competing interests}

The authors have no conflicting financial interests to declare.

\section{Database linking}

According to the Minimum Information About a Microarray Experiment (MIAME), the microarray raw data has been deposited in the GEO database, with the accession number GEO: GSE66598.

\section{Acknowledgments}

The authors would like to acknowledge Pedro Moreira, Madalena Esteves and Dr. Patrício Costa (all from the ICVS/3B's PT Government Associate Laboratory) for comments and scientific input regarding the statistical analysis of this study. Sandro Dá Mesquita and Ana C. Ferreira are recipients of PhD fellowships by the Fundação para a Ciência e Tecnologia (FCT, Portugal)/FEDER and Programa Operacional Potencial Humano (POPH/FSE), references SFRH/BD/69706/2010 and SFRH/BD/51989/2012, respectively. Fernanda Marques is an assistant researcher and recipient of a FCT Investigator Grant with the reference IF/00231/2013. This work was supported by FCT and COMPETE through the project EXPL/NEU-OSD/2196/2013 and the Bial Foundation through the Grant 217/12.

\section{Appendix A. Supplementary data}

Supplementary data associated with this article can be found, in the online version, at http://dx.doi.org/10.1016/j.bbi.2015.06.008.

\section{References}

Akwa, Y. Hassett, D.E., Eloranta, M.L., Sandberg, K., Masliah, E., Powell, H., Whitton, J.L., Bloom, F.E., Campbell, I.L., 1998. Transgenic expression of IFN-alpha in the central nervous system of mice protects against lethal neurotropic viral infection but induces inflammation and neurodegeneration. J. Immunol. 161, 5016-5026.

Ballard, C., Gauthier, S., Corbett, A., Brayne, C., Aarsland, D., Jones, E., 2011. Alzheimer's disease. Lancet 377, 1019-1031.

Baron, R., Babcock, A.A., Nemirovsky, A., Finsen, B., Monsonego, A., 2014. Accelerated microglial pathology is associated with Abeta plaques in mouse models of Alzheimer's disease. Aging Cell 13, 584-595.

Baruch, K. Schwartz, M., 2013. CNS-specific T cells shape brain function via the choroid plexus. Brain Behav. Immun. 34, 11-16.

Baruch, K., Ron-Harel, N., Gal, H., Deczkowska, A., Shifrut, E., Ndifon, W., MirlasNeisberg, N., Cardon, M., Vaknin, I., Cahalon, L., Berkutzki, T., Mattson, M.P. Gomez-Pinilla, F., Friedman, N., Schwartz, M., 2013. CNS-specific immunity at the choroid plexus shifts toward destructive Th2 inflammation in brain aging. Proc. Natl. Acad. Sci. USA 110, 2264-2269. 
Baruch, K., Deczkowska, A., David, E., Castellano, J.M., Miller, O., Kertser, A., Berkutzki, T., Barnett-Itzhaki, Z., Bezalel, D., Wyss-Coray, T., Amit, I., Schwartz, M., 2014. Aging-induced type I interferon response at the choroid plexus negatively affects brain function. Science 346, 89-93.

Beauquis, J., Vinuesa, A., Pomilio, C., Pavia, P., Galvan, V., Saravia, F., 2014. Neuronal and glial alterations, increased anxiety, and cognitive impairment before hippocampal amyloid deposition in PDAPP mice, model of Alzheimer's disease. Hippocampus 24, 257-269.

Blasko, I., Marx, F., Steiner, E., Hartmann, T., Grubeck-Loebenstein, B., 1999. TNFalpha plus IFNgamma induce the production of Alzheimer beta-amyloid peptides and decrease the secretion of APPs. FASEB J. 13, 63-68.

Browne, T.C., McQuillan, K., McManus, R.M., O’Reilly, J.A., Mills, K.H., Lynch, M.A., 2013. IFN-gamma Production by amyloid beta-specific Th1 cells promotes microglial activation and increases plaque burden in a mouse model of Alzheimer's disease. J. Immunol. 190, 2241-2251.

Carro, E., Trejo, J.L., Gomez-Isla, T., LeRoith, D., Torres-Aleman, I., 2002. Serum insulin-like growth factor I regulates brain amyloid-beta levels. Nat. Med. 8, 1390-1397.

Carro, E., Spuch, C., Trejo, J.L., Antequera, D., Torres-Aleman, I., 2005. Choroid plexus megalin is involved in neuroprotection by serum insulin-like growth factor I. J. Neurosci. 25, 10884-10893.

Coppola, G., 2011. Designing, performing, and interpreting a microarray-based gene expression study. Methods Mol. Biol. 793, 417-439.

Coppola, G., Karydas, A., Rademakers, R., Wang, Q., Baker, M., Hutton, M., Miller, B.L., Geschwind, D.H., 2008. Gene expression study on peripheral blood identifies progranulin mutations. Ann. Neurol. 64, 92-96.

Costello, D.A., Lynch, M.A., 2013. Toll-like receptor 3 activation modulates hippocampal network excitability, via glial production of interferon-beta. Hippocampus 23, 696-707.

Fu, Y., Rusznak, Z., Kwok, J.B., Kim, W.S., Paxinos, G., 2014. Age-dependent alterations of the hippocampal cell composition and proliferative potential in the hAbetaPPSwInd-J20 mouse. J. Alzheimers Dis. 41, 1177-1192.

Ghosh, S., Wu, M.D., Shaftel, S.S., Kyrkanides, S., LaFerla, F.M., Olschowka, J.A., O'Banion, M.K., 2013. Sustained interleukin-1beta overexpression exacerbates tau pathology despite reduced amyloid burden in an Alzheimer's mouse model. J. Neurosci. 33, 5053-5064.

Gotz, J., Chen, F., van Dorpe, J., Nitsch, R.M., 2001. Formation of neurofibrillary tangles in P3011 tau transgenic mice induced by Abeta 42 fibrils. Science 293, 1491-1495.

Hardy, J., Selkoe, D.J., 2002. The amyloid hypothesis of Alzheimer's disease: progress and problems on the road to therapeutics. Science 297, 353-356.

He, J., Hsuchou, H., He, Y., Kastin, A.J., Wang, Y., Pan, W., 2014. Sleep restriction impairs blood-brain barrier function. J. Neurosci. 34, 14697-14706.

Johanson, C., McMillan, P., Tavares, R., Spangenberger, A., Duncan, J., Silverberg, G., Stopa, E., 2004. Homeostatic capabilities of the choroid plexus epithelium in Alzheimer's disease. Cerebrospinal Fluid Res. 1, 3.

Kunis, G., Baruch, K., Rosenzweig, N., Kertser, A., Miller, O., Berkutzki, T., Schwartz, M., 2013. IFN-gamma-dependent activation of the brain's choroid plexus for CNS immune surveillance and repair. Brain 136, 3427-3440.

Lewis, J., Dickson, D.W., Lin, W.L., Chisholm, L., Corral, A., Jones, G., Yen, S.H., Sahara, N., Skipper, L., Yager, D., Eckman, C., Hardy, J., Hutton, M., McGowan, E., 2001. Enhanced neurofibrillary degeneration in transgenic mice expressing mutant tau and APP. Science 293, 1487-1491.

Lucin, K.M., Wyss-Coray, T., 2009. Immune activation in brain aging and neurodegeneration: too much or too little? Neuron 64, 110-122.

Marques, F., Sousa, J.C., Coppola, G., Falcao, A.M., Rodrigues, A.J., Geschwind, D.H., Sousa, N., Correia-Neves, M., Palha, J.A., 2009. Kinetic profile of the transcriptome changes induced in the choroid plexus by peripheral inflammation. J. Cereb. Blood Flow Metab. 29, 921-932.

Marques, F., Sousa, J.C., Sousa, N., Palha, J.A., 2013. Blood-brain-barriers in aging and in Alzheimer's disease. Mol. Neurodegener. 8, 38.

Mastrangelo, M.A., Sudol, K.L., Narrow, W.C., Bowers, W.J., 2009. Interferon\{gamma\} differentially affects Alzheimer's disease pathologies and induces neurogenesis in triple transgenic-AD mice. Am. J. Pathol. 175, 2076-2088.

Mazen, A.M.M., Hemmasi, M., Lewis, M.F., 1985. In search of power: a statistical power analysis of contemporary research in strategic management. Acad. Manage. Proc. 1985, 30-34.
Medeiros, R., LaFerla, F.M., 2013. Astrocytes: conductors of the Alzheimer disease neuroinflammatory symphony. Exp. Neurol. 239, 133-138.

Mesquita, S.D., Ferreira, A.C., Falcao, A.M., Sousa, J.C., Oliveira, T.G., Correia-Neves, M., Sousa, N., Marques, F., Palha, J.A., 2014. Lipocalin 2 modulates the cellular response to amyloid beta. Cell Death Differ. 21, 1588-1599.

Monsonego, A., Imitola, J., Petrovic, S., Zota, V., Nemirovsky, A., Baron, R., Fisher, Y. Owens, T., Weiner, H.L., 2006. Abeta-induced meningoencephalitis is IFNgamma-dependent and is associated with T cell-dependent clearance of Abeta in a mouse model of Alzheimer's disease. Proc. Natl. Acad. Sci. USA 103, 50485053.

Mucke, L., Masliah, E., Yu, G.Q., Mallory, M., Rockenstein, E.M., Tatsuno, G., Hu, K. Kholodenko, D., Johnson-Wood, K., McConlogue, L., 2000. High-level neuronal expression of abeta 1-42 in wild-type human amyloid protein precursor transgenic mice: synaptotoxicity without plaque formation. J. Neurosci. 20, 4050-4058.

Palop, J.J., Mucke, L., 2010. Amyloid-beta-induced neuronal dysfunction in Alzheimer's disease: from synapses toward neural networks. Nat. Neurosci. 13, 812-818.

Palop, J.J., Chin, J., Roberson, E.D., Wang, J., Thwin, M.T., Bien-Ly, N., Yoo, J., Ho, K.O. Yu, G.Q., Kreitzer, A., Finkbeiner, S., Noebels, J.L., Mucke, L., 2007. Aberrant excitatory neuronal activity and compensatory remodeling of inhibitory hippocampal circuits in mouse models of Alzheimer's disease. Neuron 55, 697-711.

Querfurth, H.W., LaFerla, F.M., 2010. Alzheimer's disease. N. Engl. J. Med. 362, 329344.

Roberson, E.D., Mucke, L., 2006. 100 years and counting: prospects for defeating Alzheimer's disease. Science 314, 781-784.

Scheuner, D., Eckman, C., Jensen, M., Song, X., Citron, M., Suzuki, N., Bird, T.D., Hardy, J., Hutton, M., Kukull, W., Larson, E., Levy-Lahad, E., Viitanen, M., Peskind, E. Poorkaj, P., Schellenberg, G., Tanzi, R., Wasco, W., Lannfelt, L., Selkoe, D. Younkin, S., 1996. Secreted amyloid beta-protein similar to that in the senile plaques of Alzheimer's disease is increased in vivo by the presenilin 1 and 2 and APP mutations linked to familial Alzheimer's disease. Nat. Med. 2, 864-870.

Scholtzova, H., Kascsak, R.J., Bates, K.A., Boutajangout, A., Kerr, D.J., Meeker, H.C., Mehta, P.D., Spinner, D.S., Wisniewski, T., 2009. Induction of toll-like receptor 9 signaling as a method for ameliorating Alzheimer's disease-related pathology. J. Neurosci. 29, 1846-1854.

Scholtzova, H., Chianchiano, P., Pan, J., Sun, Y., Goni, F., Mehta, P.D., Wisniewski, T., 2014. Amyloid beta and Tau Alzheimer' disease related pathology is reduced by Toll-like receptor 9 stimulation. Acta Neuropathol. Commun. 2, 101.

Serot, J.M., Zmudka, J., Jouanny, P., 2012. A possible role for CSF turnover and choroid plexus in the pathogenesis of late onset Alzheimer's disease. J. Alzheimers Dis. 30, 17-26.

Sousa, J.C., Cardoso, I., Marques, F., Saraiva, M.J., Palha, J.A., 2007. Transthyretin and Alzheimer's disease: where in the brain? Neurobiol. Aging 28, 713-718.

Taylor, J.M., Minter, M.R., Newman, A.G., Zhang, M., Adlard, P.A., Crack, P.J., 2014 Type-1 interferon signaling mediates neuro-inflammatory events in models of Alzheimer's disease. Neurobiol. Aging 35, 1012-1023.

Villeda, S.A., Luo, J., Mosher, K.I., Zou, B., Britschgi, M., Bieri, G., Stan, T.M., Fainberg N., Ding, Z., Eggel, A., Lucin, K.M., Czirr, E., Park, J.S., Couillard-Despres, S., Aigner, L., Li, G., Peskind, E.R., Kaye, J.A., Quinn, J.F., Galasko, D.R., Xie, X.S., Rando, T.A. Wyss-Coray, T., 2011. The ageing systemic milieu negatively regulates neurogenesis and cognitive function. Nature 477, 90-94.

Wright, A.L., Zinn, R., Hohensinn, B., Konen, L.M., Beynon, S.B., Tan, R.P., Clark, I.A. Abdipranoto, A., Vissel, B., 2013. Neuroinflammation and neuronal loss precede Abeta plaque deposition in the hAPP-J20 mouse model of Alzheimer's disease. PLOS ONE 8, e59586.

Wyss-Coray, T., 2006. Inflammation in Alzheimer disease: driving force, bystander or beneficial response? Nat. Med. 12, 1005-1015.

Zhang, E.E., Kay, S.A., 2010. Clocks not winding down: unravelling circadian networks. Nat. Rev. Mol. Cell Biol. 11, 764-776.

Zlokovic, B.V., 2008. The blood-brain barrier in health and chronic neurodegenerative disorders. Neuron 57, 178-201. 